Volume 4, Nomor 1, 2021, hlm. 63-88

P-ISSN: 2622-2280 | E-ISSN: 2622-4658

https://ejurnal.iiq.ac.id/index.php/alfanar

DOI: $10.33511 /$ alfanar.v4n1.63-88

\title{
Makna Al-Hamd dan Al-Syukr dalam Tafsir
}

(Studi Analisis Metode Tafsir Muqarran)

\author{
Eva 'Uyuni Maesyaroh \\ UIN Syarif Hidayatullah Jakarta \\ eva.uyuni@gmail.com
}

\begin{abstract}
:
This article discusses the interpretation of the words al-hamd and al-syukr. The word al-hamd is commonly used in everyday life as a compliment or an expression of gratitude for the pleasure obtained, in Arabic the word hamd is equated with the words thanā', madh, ni'ma, and syukr. but not found in the Al-Qur'an except the words hamd, syukr, and ni'ma. It is stated that in the Qur'an many words are mutarädif but in fact have their own connotations, referring to this, of course, contains different explanations both in terms of meaning and usage. Therefore, a special study through interpretation is needed because in the interpretation it is found that the two words are disputed. In analyzing these two words using the approach of the muqarran interpretation method on verses related to al-hamd and al-syukr in the AlQur'an which focuses on the views of al-Țabarī, al-Qurțbì and ibn Kathīr. The aim that the writer wants to achieve in this study is the disclosure of al-hamd and al-syukr according to tafsir scholars.
\end{abstract}

Keywords: al-Hamd, al-Syukr, al-Tabarī, al-Qurțubī, Ibn Kathīr

\begin{abstract}
Abstrak:
Artikel ini membahas penafsiran kata al-hamd dan al-syukr. Kata al-hamd lazim digunakan dalam kehidupan sehari-hari sebagai pujian atau ungkapan syukur atas kenikmatan yang didapatkan, dalam bahasa Arab kata hamd disamakan dengan kata thanā', madh, ni'ma, dan syukr. tetapi tidak ditemukan dalam Al-Qur'an kecuali kata hamd, syukr, dan ni'ma. Disebutkan bahwa dalam Al-Qur'an banyak kosa kata yang mutarādif tetapi ternyata memiliki konotasinya sendiri, mengacu pada hal tersebut tentunya mengandung penjelasan yang berbeda baik makna dan penggunaannya. Oleh karenanya, dibutuhkan kajian khusus melalui penafsiran sebab pada penafsirannya ditemukan bahwa kedua kata tersebut ternyata diperdebatkan. Dalam menganalisis kedua kata tersebut menggunakan pendekatan metode tafsir muqarran pada ayat-ayat yang terkait dengan al-hamd dan al-syukr dalam Al-Qur'an yang terfokus pada pandangan al-Tabarī, al-Qurțubì dan ibn Kathìr. Tujuan yang ingin dicapai penulis dalam penelitian ini adalah pengungkapan al-hamd dan al-syukr menurut ulama tafsir.
\end{abstract}

Kata Kunci: al-Hamd, al-Syukr, al-Ṭabarī, al-Qurțubī, Ibn Kathīr 
Makna Al-Hamd dan Al-Syukr dalam Tafsir

(Studi Analisis Metode Tafsir Muqarran)

\section{PENDAHULUAN}

Terkadang bahasa Al-Qur`an memberi makna baru dalam bahasa Arab, ${ }^{1}$ karena kata dan kalimatnya yang singkat namun menampung banyak makna. ${ }^{2}$ Setiap kata dalam Al-Qur`an memiliki makna sendiri dan tidak bisa diganti dengan kata lain. ${ }^{3}$ Kata yang memiliki makna sama dalam ilmu bahasa (lingustik) disebut sinonim, dalam bahasa arab disebut at-Tarāduf (الترادف).

Meskipun hampir dapat dikatakan bahwa mayoritas pakar mengakui adanya musytarak dan mutarādif, namun beberapa menolak hal tersebut. ${ }^{4}$ Muhammad Syahrur termasuk tokoh yang menolak sinonimitas, menurutnya jika menerima sinonimitas sama dengan menolak historisitas dari perkembangan bahasa. ${ }^{5}$ Begitu pun dengan Bintu Syathi yang menyatakan setiap lafal memiliki dalalah tertentu, tidak mungkin dapat diganti dengan lafal lain yang mempunyai makna sama sebagai murādif. ${ }^{6}$

Said Nursi mengemukakan penyebab terjadinya distorsi makna karena hanya berpatokan pada tekstualnya saja, dan tidak memperhatikan maq $\bar{a}$ sidnya serta kurangnya penguasaan bahasa Arab. ${ }^{7}$ Faktor tersebut mengalihkan penafsiran dari tujuan utama menuju tujuan yang lain, ${ }^{8}$ begitu juga praktik di masyarakat yang memahami makna Al-Qur'an hanya berdasarkan terjemahan, tidak dengan melihat konsep asal katanya. Sehingga, hal itu dapat mengubah beberapa makna istilah penting yang terdapat pada bahasa asli Al-Qur'an serta berdampak kurang baik terhadap pemahaman ayat.

Setiap kata dalam Al-Qur’an disebutkan dalam ilmu balaghah, memiliki makna yang berbeda dengan konotasi sendiri meskipun sama dalam bentuk tekstualnya. Seperti kata al-hamd dan al-syukru. Kata al-hamd lazim digunakan dalam kehidupan sehari-hari, sebagai pujian atau ungkapan syukur seseorang ketika memperoleh atau mendengar berita gembira. ${ }^{9}$ Pujian adalah ekspresi manusia berupa ungkapan hati yang ditujukan kepada Allah, karena sifat-sifat kesempurnaan-Nya dan sebagai tanggapan atas perbuatan-Nya. ${ }^{10}$ Sebaik-baik kalimat adalah pujian kepada Allah Ta'ala. Sebagaimana hadis:

${ }^{1}$ Sugeng Sugiyono, Lisan dan Kalam Kajian Semantik Al-Qur `an (Yogyakarta: Sunan Kalijaga Press, 2009), h. 3.

${ }^{2}$ M. Quraish Shihab, Mukjizat Al-Qur 'an (Bandung: Anggota Ikapi, 2007), h. 120.

${ }^{3}$ Mahmud Saltut, Tafsīr Al-Qur `ān al-Karīm (Bandung: Sinar Baru Algensindo, 2000), h. 786.

${ }^{4}$ M. Quraish Shihab, Kaidah Tafsir: Syarat, dan Ketentuan yang Patut Anda Ketahui dalam Memahami Al-Qur'an (Tangerang: Lentera Hati, 2015), h. 30.

${ }^{5}$ Asriaty, "Menyoal Pemikiran Islam Syahrur", Istinbat: Jurnal Hukum Islam, Vol. 13, No. 2 (Desember 2014), h. 219.

${ }^{6}$ Namedia, "Metodologi Penafsiran Dr. Aisyah Abdurrahman (Bintu Syathi)", Diakses 11 Oktober, 2019, https://milahidayah.wordpress.com/2014/10/01/metodologi-penafsiran-dr-aisyahabdurrahman-bintu-syathi/.

7 Moh. Bakir, “Konsep Maqāsid Al-Qur’ān Perspektif Bad̄̄ al-Zamān Sa‘̄̄d Nursī (Upaya Memahami Makna al-Qur’an Sesuai dengan Tujuannya)”, Jurnal Elfurqonia Al-Mujtama ‘ Pamekasan, Vol. 1, No. 1 (Agustus 2015), h. 50-51.

${ }^{8}$ Muhammad Rasyīd Ridā, Tafsīr Al-Qur `ān al-Hakīm (al-Manār), Cet. I (Beirūt: Dār al-Kutub al-'Ilmiyah, 1999), h. 21.

${ }^{9}$ Abu Zahwa, Tafsir Surah al-Fatihah Menurut 10 Ulama Besar Dunia (Jakarta: Pustaka Azzam, 2010), h. 363.

10 Syaikh Abdurrahmān bin Nașir al-Sa'di Zulharman, Taisir al-Karīm al-Rahmān fī Tafsīr Kalām al-Mannān, Cet. II (KSA: Dār Ibn al-Jauzi, 1426), h. 66.

64 | Al-Fanar: Jurnal Ilmu Al-Qur'an dan Tafsir 


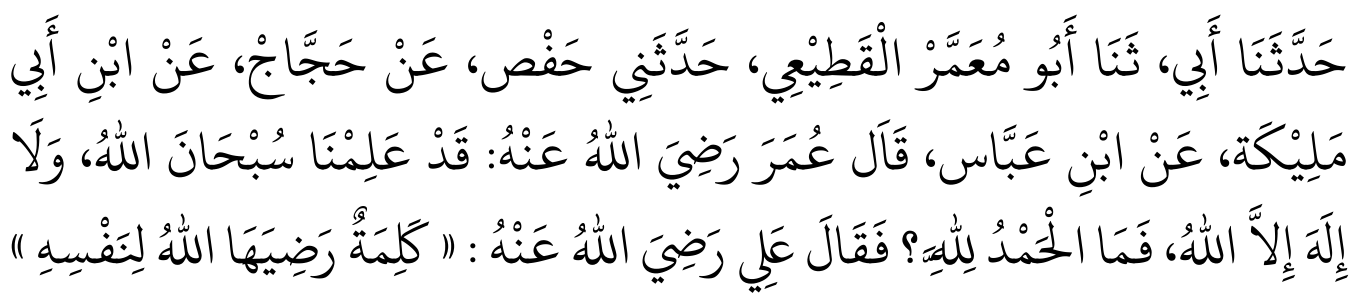

"Dari Ibnu 'Abbās bahwa 'Umar bin al-Khattāa berkata: "Sesungguhnya kita telah mengetahui (maksud ucapan) Subhānallāh dan Lā ilāhaillallāh, lalu apa yang dimaksud dengan (ucapan) Alhamdulillāh? 'Alī bin Abi Tālib berkata: (Alhamdulillāh) adalah (ucapan) kalimat yang telah diridai Allah untuk diriNya." (HR. Ibnu Hātim)."11

Kata alhamdulillāh merupakan kalimat yang menjadi bentuk hubungan penghambaan seorang hamba kepada Tuhannya. ${ }^{12}$ Sehingga secara lengkap kalimat alhamdulillāh mempunyai makna penegasan bahwa "segala macam pujian hakikatnya adalah berasal dari Allah dan untuk Allah". ${ }^{13}$ Kalimat ini merupakan ungkapan terima kasih yang ditujukan kepada Allah Swt. atas segala nikmat dan anugerah yang diberikan-Nya. ${ }^{14}$ Sebagaimana firman Allah

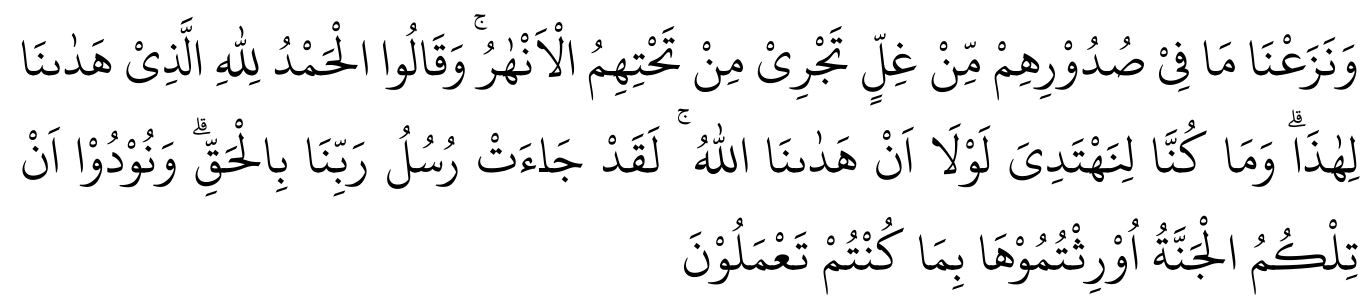

"Dan Kami mencabut rasa dendam dari dalam dada mereka, di bawahnya mengalir sungai-sungai. Mereka berkata, "Segala puji bagi Allah yang telah menunjukkan kami ke (surga) ini. Kami tidak akan mendapat petunjuk sekiranya Allah tidak menunjukkan kami. Sesungguhnya rasul-rasul Tuhan kami telah datang membawa kebenaran." Diserukan kepada mereka, "Itulah surga yang telah diwariskan kepadamu, karena apa yang telah kamu kerjakan.” (QS. AlA'rāf [7]: 43).

Sedangkan kata syakūr terambil dari kata syakara yang maknanya berkisar antara lain pada pujian atas kebaikan, serta penuhnya sesuatu. Dalam Al-Qur`an kata syukur biasa dihadapkan dengan kata kufur, seperti firman Allah:

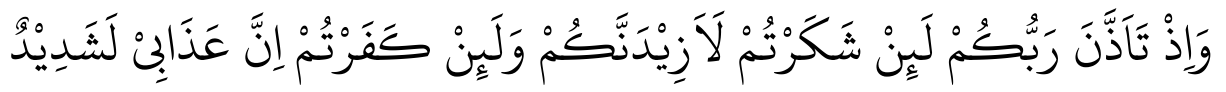

"Dan (ingatlah) ketika Tuhanmu memaklumkan, "Sesungguhnya jika kamu bersyukur, niscaya Aku akan menambah (nikmat) kepadamu, tetapi jika kamu mengingkari (nikmat-Ku), maka pasti azab-Ku sangat berat.”(QS. Ibrāhīm [14]: 7)

${ }^{11}$ Ahmad bin Ibrahim bin Kholid al-Muṣalli, Tafsīr ibn Abī Hātim, J. 1 (t.t), h. 22.

${ }^{12}$ Egi Sukma Baihaki, "Syukur dan Pujian Menurut Muhammad Shaleh Darat al-Samarani: Kajian atas (QS. al-Fātiḥah/1:2) Tafsīr Faị̣ al-Raḥmān”, Jurnal Tanzil Sekolah Tinggi Filsafat Islam Jakarta, Vol.1, No.2, (April 2016), h. 215.

${ }^{13}$ Abdul Malik Karim Amrullah, Tafsìr al-Azhār, J. 1 (Jakarta: Pustaka Panjimas, 1986), h. 78.

${ }^{14}$ Muhammad al-Ghazālī, Tafsìr al-Ghazālī: Tafsir Tematik Al-Qur'an 30 Juz (Surat 1-26), terj. Safir al-Azhar (Yogyakarta: Islamika, 2004), h. 3. 
Ini disebabkan karena syukur juga diartikan sebagai menampakkan sesuatu ke permukaan, sedang kufur adalah menutupinya. Menampakkan nikmat Tuhan antara lain dengan bentuk memberi sebagian dari nikmat itu kepada pihak lain, sedang menutupinya adalah dengan bersifat kikir. ${ }^{15}$ Tidak bersyukur atas nikmat yang Allah berikan sama saja dengan kufur nikmat. Imam al-Ghazālī menegaskan bahwa disebutnya perintah bersyukur bergandengan dengan perintah berzikir (mengingat Allah) menunjukkan bahwa bersyukur memiliki kedudukan yang penting. ${ }^{16}$ Allah berfirman:

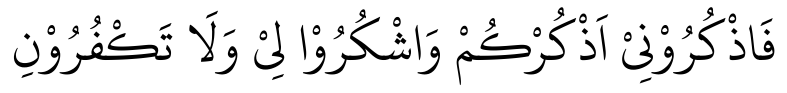

"Maka ingatlah kepada-Ku, Aku pun akan ingat kepadamu. Bersyukurlah kepada-Ku, dan janganlah kamu ingkar kepada-Ku. (QS. al-Baqarah [2]: 152)

Banyak ditemukan ayat-ayat dalam Al-Qur'an yang berdekatan maknanya akan tetapi berbeda dalam redaksinya. Bentuk ekspresi ucapan terima kasih atas anugerah yang diberikan Allah dalam bahasa Arab dapat menggunakan kata hamd, tsanā', madh, syukr. ${ }^{17}$ Kata hamd merupakan bentuk mașdar dari kata hamida-yahmadu-hamdan yang bermakna memuji, dan dalam bahasa Arab kata yang mempunyai makna yang lebih dekat dengan lafal al-hamd adalah al-syukru. ${ }^{18}$

Selain dari kata al-hamd yang sering digunakan untuk mengungkapkan terima kasih dan juga pemaknaannya yang dekat, terdapat perbedaan penafsiran yang ditemukan pada kata al-hamd dan al-syukr. Ibn Jarīr al-Ṭabarī pada tafsirnya yang dikenal sebagai kitab tafsir bi al-ma 'thür terbesar menyatakan bahwa kata al-hamd dan al-syukr sebagai sinonim, ${ }^{19}$ dengan alasan karena orang Arab sering menggunakan keduanya dalam satu ungkapan:

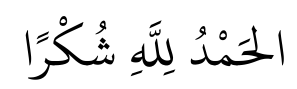

"Segala puji bagi Allah sebagai ungkapan rasa syukur."

Dari pengertian kedua tersebut, al-Qurțubī menyatakan penolakannya, menurutnya pengertian kedua kata tersebut berbeda. Memuji (hamd) berarti ucapan yang ditujukan kepada yang dipuji atas sifat, sikap dan perbuatannya tanpa didahului oleh jasa baiknya kepada pemuji. Hal ini berbeda dengan syukr yang berarti memuji pihak yang dipuji lantaran kebaikan yang telah diberikannya kepada pemuji. ${ }^{20}$

Terlepas dari salah satu perbedaan pendapat para ulama, seperti yang telah penulis sebutkan maka timbullah pertanyaan atas makna dan penggunaan dari kedua kata tersebut. Berdasarkan masalah tersebut penulis tertarik dan merasa penting untuk

${ }^{15}$ Sahabuddin. Ensiklopedia Al-Qur 'an, h. 939-940.

${ }^{16}$ Abū Hāmid al-Ghazālī, Ihyā' 'Ulūm al-Dīn, J. 4 (Beirut: Dār al-Fikr, t.t), h. 80.

${ }^{17}$ Ab̄̄ al-Qāsim al-Husain bin Muhammad, Mu 'jam Mufradāt al-Fāz Al-Qur 'àn (Beirūt: Dār alKitab al-'Ilmiyah, t.t), h. 147.

${ }^{18}$ Sahabuddin. Ensiklopedia al-Qur'an: Kajian Kosakata (Jakarta: Lentera Hati, 2007), h. 279.

${ }^{19}$ Abū Ja'far Muhammad bin Jarīr al-Ṭabarī, Tafsir Jāmi ‘ al-Bayān, terj. Ahmad Abdurrazzaq al-Bakri, dkk (Jakarta: Pustaka Azzam, 2007), h. 218-221.

${ }^{20}$ Abū 'Abdillāh al-Qurțub̄̄, al-Jāmi' li Aḥkām Al-Qur'an, terj. Fathurrahman, dkk (Jakarta: Pustaka Azzam, 2010), 339-343. Lihat juga, Muhammad 'Ālī al-Ṣābūn̄̄, Rawāi ' al-Bayān Tafsīr Ayat al-Aḥkām min al-Qur `an, J. 1 (Damaskus: Maktabah al-Gazālī, 1977), h. 23. 
membahas hal ini. Bagaimana pemaknaan kata al-hamd dan al-syukr dalam tafsir.

Banyaknya mufasir yang menjelaskan tentang penafsiran lafal tersebut, maka penulis menggunakan kitab tafsir al-Ṭabarī mufasir klasik dan al-Qurțubī mufasir abad pertengahan yang sama-sama dipandang sebagai kitab yang mendahulukan penafsiran melalu riwayat- riwayat serta menafsirkan kedua lafal tersebut dengan sudut pandang yang berbeda-beda seperti penjelasan di atas, serta menggunakan tafsir Ibn Kathīr sebagai penengah dengan penjelasannya yang detail. Sesuai dengan identifikasi dan pembatasan masalah di atas, dapat dirumuskan pokok permasalahan dalam penelitian ini yaitu: "Bagaimana Pemaknaan Kata al-Hamd dan al-Syukr dalam tafsir al-Ṭabarī, al-Qurțubī, dan Ibn Kathīr?”

\section{PENGERTIAN KATA $A L-H A M D$ DAN $A L-S Y U K R$ Pengertian Kata al-Hamd}

Kata al-hamd berasal dari bahasa Arab yang sering diterjemahkan dalam bahasa Indonesia sebagai pujian/sanjungan yang berarti (pernyataan) pengakuan dan penghargaan kepada sesuatu (yang dianggap baik, indah, gagah berani, dan sebagainya). ${ }^{21}$ Sesuai bahasa asalnya, kata al-hamd adalah bentuk mașdar dari kata hamida-yahmadu-ḥamdan. Kata tersebut terdiri dari tiga huruf, yakni ha, mim dan dal yang berarti madaha yang artinya memuji atau antonim dari kata al-khațau wa al-zammu yang artinya tercela dan salah. Begitu juga dengan kata ahmadu (yang lebih terpuji), mahmūidun, muḥammad (yang terpuji) dan taḥmìd (mengucapkan pujian) yang berasal dari akar kata yang sama. ${ }^{22}$

Kata al-hamd yang merupakan penggalan dari alhamdulillāh lazim digunakan dalam kehidupan sehari-hari, sebagai ungkapan syukur seseorang ketika memperoleh atau mendengar berita gembira. ${ }^{23}$ Menurut ulama, kata (al) yang mengiringi (hamd) bermakna segala. Sedangkan huruf (lam) sebelum kata Allah (li Allāh) mengandung makna yang dikhususnya bagi-Nya. ${ }^{24}$ Al-Khațib al-Syirbinī dalam kitabnya al-Iqna' mengatakan bahwa kata al-hamd mengandung makna ath-thanā' al-kāmil (pujian yang sempurna), karena itu hanya Allah-lah yang berhak untuk diberi ungkapan alhamd dengan sifat kesempurnaannya, meski mengatakan al-hamd untuk sesama tidak dilarang.

Rāghib al-Aṣfahān̄̄ menyebutkan bahwa tahmid (alhamdulillāh) yaitu pujian kepada Allah atas keunggulan yang Allah miliki, dan hamd lebih khusus dari madh dan lebih umum dari al-syukr. Sesungguhnya al-madh dilakukan seseorang kepada manusia tanpa paksaan, terkadang juga diucapkan karena ketakjuban. Pertama, manusia memuji manusia sesamanya atas derajat sosial yang tinggi dan keelokan fisiknya. Kedua, pujian juga dilakukan untuk kebaikan, kemurahan hati dan pengetahuannya. Sedangkan yang

21 Tim Penyusun Kamus Pusat Pembinaan dan Pengembangan Bahasa, Kamus Besar Bahasa Indonesia, Cet. IV (Jakarta: Balai Pustaka, 1990), h. 706-707.

${ }^{22}$ Sahabuddin. Ensiklopedia al-Qur 'an: Kajian Kosakata (Jakarta: Lentera Hati, 2007), h. 279.

${ }^{23}$ Abu Zahwa, Tafsir Surah Al-Fatihah Menurut 10 Ulama Besar Dunia (Pustaka Azzam, 2010), h. 363 .

${ }^{24}$ Tasmin Tangngareng, Menyelam ke Semesta Zikir: Menyikap Makna dan Pesannya dalam Hadis Nabi Saw, Cet. I (Makassar: Alauddin University Press, 2013), h. 49. 
dikatakan al-hamd adalah pujian yang kedua bukan yang pertama. Kemudian al-syukr tidak dilakukan tanpa adanya nikmat, maka segala syukur adalah al-hamd, dan al-hamd belum tentu syukur. Sedangkan setiap hamd adalah madh, dan setiap madh belum tentu hamd. ${ }^{25}$

Kata al-hamd ditemukan dalam Al-Qur`an sebanyak 68 kali pada 44 surah, ${ }^{26}$ yaitu dalam QS. al-Fātiḥah [1]: 1 kali, al-Baqarah [2]: 2 kali pengulangan, Āli 'Imrān [3]: 2 kali pengulangan, al-Nisā' [4]: 1 kali, al-An'ām [6]: 2 kali pengulangan, al-A'rāf [7]: 1 kali, al-Taubah [9]: 1 kali, Yūnus [10]: 1 kali, Hūd [11]: 1 kali, al-Ra'du [13]: 1 kali, Ibrāhīm [14]: 3 kali pengulangan, al-Ḥijr [15] 1kali, al-Naḥl [16]: 1 kali, alIsrā' [17]: 4 kali pengulangan, al-Kahfi [18]: 1 kali, Tāhā [20]: 1 kali, al-Hajj [22]: 2 kali pengulangan, al-Mukminūn [23]: 1 kali, al-Furqān [25]: 1 kali, al-Naml [27]: 3 kali pengulangan, al-Qașaș [28]: 1 kali, al-'Ankabūt [29]: 1 kali, al-Rūm [30]: 1 kali, Luqmān [31]: 3 kali pengulangan, al-Sajdah [32]: 1 kali, al-Aḥzāb [33]: 1 kali, Sabā' [34]: 2 kali pengulangan, Fāṭir [35]: 3 kali pengulangan, al-Șaffat [37]: 1 kali, al-Zumar [39]: 3 kali pengulangan, Gāfir [40]: 3 kali pengulangan, Fuṣṣilat [41]: 1 kali, al-Syūrā [42]: 2 kali pengulangan, al-Jāthiah [45]: 1 kali, Muhammad [47]: 1 kali, al-Fath [48]: 1 kali, Qaf [50]: 1 kali, al-Ṭūr [52]: 1 kali, al-Ḥadīd [57]: 1 kali, al-Mumtahanah [60]: 1 kali, al-Șaff [61]: 1 kali, al-Taghābun [64]: 2 kali pengulangan, al-Burūj [85]: 1 kali dan al-Nașr [110]: 1 kali pengulangan. ${ }^{27}$

\section{Pengertian Kata al-Syukr}

Kata syakūr terambil dari kata syakara yang maknanya berkisar antara lain pada pujian atas kebaikan, serta penuhnya sesuatu. Kata syukūr adalah bentuk mașdar dari kata kerja syakara-yasykuru-syukran-wasyukūran-wasyukrānan, yang berakar dari huruf syin, kaf, dan ra'. ${ }^{28}$ Al-Syukr dalam Lisān al-'Arab, al-syukr yaitu berterima kasih atas suatu kebaikan dan menyebarkannya. Tsa'lab berkata; syukur dilakukan hanya karena mendapatkan nikmat, sedangkan al-ḥamd dilakukan karena mendapatkan dan tidak mendapatkan nikmat. Bersyukur atas nikmat yang diberikan oleh Allah bermakna membalas jasa dan pujian yang baik. ${ }^{29}$

Rāghib al-Aṣfahānī mengatakan al-Syukr adalah menggambarkan kenikmatan dan mengungkapkannya, atau menyingkap dan memperlihatkannya. Lawan kata dari alsyukr adalah al-kufru, melupakan kenikmatan dan menutupinya. Ketika kalimat syakur didampingkan dengan kata däbbah, maka artinya hewan yang memperlihatkan giginya ketika memandang pemiliknya. dikatakan pula kata al-syukr berasal dari kata syakrā yang artinya dipenuhi, maka al-syukru asal katanya sesuai dengan kalimat syakrā bermakna penyempurnaan dengan menyebutkan kenikmatan-kenikmatan kepada-Nya. Al-syukr terdapat 3 macam, 1) syukur hati yaitu dengan menggambarkan nikmat 2)

${ }^{25}$ Rāghib al-Ashfahān̄̄, Mu’jam Mufradāt al-Fāz Al-Qur 'ān (Beirut: Dār al-Kitab al-'Ilmiah, t.t), h. 147.

${ }^{26}$ Penulis menemukan lafal al-hamd dengan derivasinya terdiri dari 10 kata yaitu: يُحَدُو ار, الحَمْدُ,

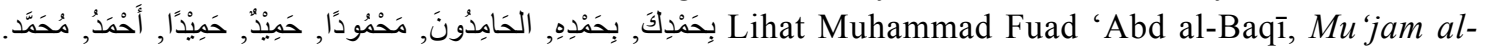
Mufahras lī al-Faz al-Qur 'àn al-Karīm (Kairo: Dār al-Hadī̇, 2007), h. 266-268.

27 al-Baq̄ī, Mu jam al-Mufahras, h. 266-268.

${ }^{28}$ Sahabuddin. Ensiklopedia Al-Qur'an, h. 964.

${ }^{29}$ Ibn Manẓūr, Lisān al- 'Arab, J. 9 (Beirut: Dār Șādir, t.t), h. 423. 
syukur lisan yaitu memuji yang memberikan kenikmatan 3) syukur dengan anggota badan yaitu mempergunakan kenikmatan sesuai dengan hak-haknya atau fungsinya. ${ }^{30}$

Oleh karena itu ulama berpendapat syukūr berasal dari syakara yang berarti membuka dengan lawannya kafara yakni menutup dan mengandung makna melupakan nikmat dan menutupinya. Hakikat syukur adalah menampakkan nikmat antara lain menggunakannya pada tempat yang dikehendaki pemberinya, dan menyebut-nyebut nikmat dan pemberinya dengan lidah. ${ }^{31}$ Syukr dalam Maqāyis al-Lughah berasal dari kata ainun syakara yang berarti penuh, maksudnya adalah selalu mengingat orang yang memberi nikmat. ${ }^{32}$ Selain kata syukr dalam Al-Qur`an juga ditemukan kata syakur, alGhazali mengartikan syakur sebagai sifat Allah bahwa Allah yang memberikan balasan terhadap pelaku kebaikan, dan menganugerahkan nikmat yang tidak terbatas waktunya untuk amalan-amalan yang terbatas. ${ }^{33}$

Kata al-syukr disebutkan sebanyak 75 kali pada 35 surah $^{34}$ yaitu dalam QS. alBaqarah [2]: 8 kali pengulangan, Āli 'Imrān [3]: 3 kali pengulangan, al-Nisā' [4]: 2 kali pengulangan, al-Māidah [5]: 2 kali pengulangan, al-An'ām [6]: 2 kali pengulangan, al-A'rāf [7]: 5 kali pengulangan, al-Anfāl [8]: 1 kali, Yunūs [10]: 2 kali pengulangan, Yūsuf [12]: 1 kali, Ibrāhīm [14]: 4 kali pengulangan, al-Naḥl [16]: 4 kali pengulangan, al-Isrā' [17]: 2 kali pengulangan, al-Anbiyā' [21]: 1 kali, al-Hajj [22]: 1 kali, alMukminūn [23]: 1 kali, al-Furqān [25]: 1 kali, al-Naml [27]: 5 kali pengulangan, alQașaș [28]: 1 kali, al-'Ankabūt [29]: 1 kali, al-Rūm [30]: 1 kali, Luqmān [31]: 4 kali pengulangan, Saba' [34]: 4 kali pengulangan, Fāṭir [35]: 3 kali pengulangan, Yāsin [36]: 2 kali pengulangan, al-Zumar [39]: 2 kali pengulangan, Gāfir [40]: 1 kali, al-Syūrā [42]: 2 kali pengulangan, al-Jāthiah [45]: 1 kali, al-Aḥqāf [46]: 1 kali, al-Wāqiah [56]: 1 kali, al-Tagābun [64]: 1 kali, al-Mulk [67]: 1 kali dan al-Insān [76]: 3 kali pengulangan. ${ }^{35}$

\section{KLASIFIKASI AYAT-AYAT $A L-H A M D$ DAN $A L-S Y U K R$ BERDASARKAN TEMATIK}

Pembahasan selanjutnya adalah klasifikasi terhadap kata al-hamd dan al-syukr, dengan merujuk pada beberapa surah dan ayat yang berkaitan dengan kedua kata tersebut dalam al-Qur'an yang telah dipaparkan sebelumnya. Klasifikasi ini didasarkan pada metode tematik yang dipakai dalam mengumpulkan ayat dari kata al-hamd dan alsyukr, yakni berdasar pada masa turunnya ayat, asbab al-nuzul ayat, serta ayat yang mengandung 'amm dan khash.

${ }^{30}$ Rāghib al-Ashfahān̄̄, Mu'jam Mufradāt al-Fāz Al-Qur 'ān, h. 298.

${ }^{31}$ M. Quraish Shihab, Wawasan al-Qur'an: Tafsir Maudhu'i atas Pelbagai Persoalan Umat (Bandung: Mizan, 1996), h. 216.

${ }^{32}$ Aḥmad Ibn Faris ibn Zakariya, Mu’jam Maqayis al-Lughah, J. 3 (Beirut: Dār al-Fikr, t.t), h. 208.

${ }^{33}$ Sahabuddin. Ensiklopedia Al-Qur 'an, h. 966.

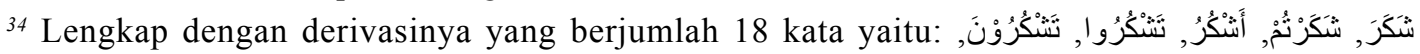

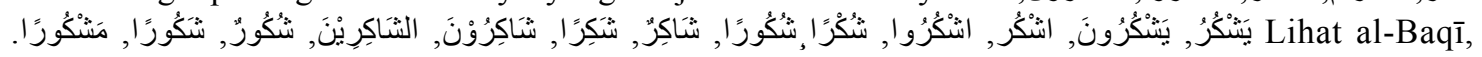
Mu ‘jam al-Mufahras, 474-475.

${ }^{35}$ al-Baq1̄, Mu 'jam al-Mufahras, 474-475. 
Makna Al-Hamd dan Al-Syukr dalam Tafsir

(Studi Analisis Metode Tafsir Muqarran)

\section{Masa Turunnya Ayat}

Ditinjau dari segi turunnya ayat Al-Qur`an, maka ada yang diklasifikasikan sebagai makkiyah atau madaniyah. Penetapan ini tidak didasarkan pada riwayat Nabi, karena dalam hal ini hanya ada periwayatan dari sahabat dan tabi' in. Adapun hitungan jumlah surah makkiyah adalah delapan puluh lima, sedangkan jumlah surah madaniyah ada dua puluh Sembilan surat. ${ }^{36}$

Suatu kewajiban mengetahui masa turunnya ayat baik itu makkiyah atau madaniyah untuk mempermudah dalam mengkaji dan memahami makna ayat Al-Qur'an, dalam hal ini khususnya kata al-hamd dan al-syukr. ${ }^{37}$ Mengetahui tempat turunnya ayat dengan berpatokan pada ayat yang dinasakh atau dimansukh juga mempermudah ketika menemukan ayat yang secara zahir kontradiktif. ${ }^{38}$

Adapun surah-surah yang berkaitan dengan kata al-hamd dan al-syukr sesuai masa turunnya dapat dilihat di bawah ini:

\begin{tabular}{|c|l|l|l|}
\hline No & \multicolumn{1}{|c|}{ Madaniyah } & \multicolumn{1}{|c|}{ Makkiyah } & $\begin{array}{c}\text { Surah yang } \\
\text { Diperselisihkan Turunnya }\end{array}$ \\
\hline 1 & QS. Ibrāhīm [14]: 39 & $\begin{array}{l}\text { QS. al-Baqarah [2]: } \\
30 \text { \& 52 }\end{array}$ & QS. al-Fātihah [1]: 2 \\
\hline 2 & QS. al-Isrā' [17]: 3 & $\begin{array}{l}\text { QS. Āli 'Imrān [3]: } \\
144 \text { \& 188 }\end{array}$ & \\
\hline 3 & QS. al-Naml [27]: 40 & QS. al-Insān [76]: 3 & \\
\hline 4 & $\begin{array}{l}\text { QS. al-'Ankabūt [29]: } \\
63\end{array}$ & & \\
\hline 5 & QS. al-Ahqāf [46]: 15 & & \\
\hline 6 & QS. al-Mulk [67]: 23 & & \\
\hline
\end{tabular}

\section{Asbāb al-Nuzūl Ayat dari Kata al-Hamd dan al-Syukr}

Asbāb al-nuzūl ayat atau sebab turunnya ayat merupakan suatu kisah yang diambil dari kejadian tertentu atau suatu pertanyaan kepada Nabi, baik mengenai peristiwa ataupun mengenai orang-orangnya yang menyebabkan turunnya suatu ayat atau beberapa ayat. Ayat-ayat itu dimaksudkan untuk menjelaskan peristiwa yang terjadi, ${ }^{39}$ dan bertujuan untuk membantu memahami ayat tersebut.

Akan tetapi tidak semua ayat Al-Qur'an diiringi dengan sebab turunnya, ada yang

${ }^{36}$ Abdul Qadir Muhammad Șālih, al-Tafsīr wa al-Mufassirūn fĩ al-Aśar al-Hadisं (Beirut: Dār al-Ma'rifah, 2003), h. 64.

37 Teungku Muhammad Hasbi al-Shiddieqy, Ilmu-ilmu Al-Qur 'an, Cet. II (Semarang: Pustaka Rizki Putra, 2009), h. 53.

${ }^{38}$ Mannā Khalīl al-Qațān, Mabāḥīs fì Ulūm Al-Qur ān, terj. Mudzakir, Studi Ilmu-ilmu alQur `an (Bogor: Pustaka Lintera Antar Nusa, 2009), h. 59.

${ }^{39}$ Mohammad Nor Ichwan, Studi Ilmu-ilmu Al-Qur an (Semarang: Rasail Media Group, 2008), h. 75 . 
diturunkan tanpa didahului sebab dan ada yang diturunkan karena ada sebab. ${ }^{40}$ Adapun menurut Mannā Khalīl al-Qaț̣ān, ayat yang turun tanpa sebab merupakan ayat-ayat yang membahas akidah atau tentang kehidupan sosial dan juga yang diturunkan sebagai permulaan surah. ${ }^{41}$

Begitu juga dengan surah atau ayat yang di dalamnya terdapat kata al-hamd dan alsyukr tidak semuanya mengandung asbab al-nuzul. Setelah diteliti, ayat-ayat dari kata al-ḥamd dalam penelitian ini yang diikuti asbāb al-nuzūl adalah surah Āli 'Imrān [3]: 188. Sedangkan dalam ayat-ayat dari kata al-syukr adalah surah Āli 'Imrān [3]: 144 dan surah al-Aḥqāf [46]: 15 saja. Namun pada surah Āli 'Imrān ayat 144 ini ditemukan juga kata hamd dengan redaksi muhammadun.

\section{Ayat-ayat yang Mengandung ' $\bar{A} m$ dan Khaș}

Dalam Al-Qur'an akan ditemukan beberapa ayat yang menunjukkan keumumannya maupun kekhususannya. Pengertian 'àm sendiri adalah lafal-lafal yang mencakup segala sesuatu tanpa pengecualian oleh kata lain, jadi ia adalah lafal yang hanya memiliki satu pengertian yang terkadang ditandai dengan bentuk-bentuk tertentu. Sedangkan khas adalah lafal yang khusus atau terbatas pada sesuatu yang ditentukan. ${ }^{42}$ Adapun ayat-ayat al-hamd dan al-syukr dalam penulisan ini yang mengandung makna 'àm dan khas akan dibahas sebagai berikut:

1. Ayat-ayat al-hamd yang mengandung makna 'àm.

a. Kata al-hamd pada surah al-Fātiḥah [1]: 2 mengandung makna umum, ditunjukkan dengan bentuk tunggal yang menggunakan "Al" al-Istighrāq. ${ }^{43}$

b. Pada Surah al-Baqarah [2]: 30 terdapat kata bihamdika, ayat ini bersifat umum dengan adanya istifham dari para malaikat kepada Allah.

c. Surah al-'Ankabūt [29]: 63 merupakan ayat yang bersifat umum karena adanya istifham ditunjukkan dengan lafal man.

2. Ayat-ayat al-syukr yang mengandung makna 'ām.

a. Surah Āli 'Imrān [3]: 144 dengan lafal al-syākirīn di dalamnya adalah ayat yang bersifat umum, karena isim yang berbentuk jamak dan menggunakan "Al" al-jins.

b. Pada Surah al-Ahqāf [46]: 15 terdapat lafal asykara, ayat ini bersifat umum ditunjukkan dengan Isim Maușūl yaitu allātī.

c. Surah al-Mulk [67]: 23 adalah ayat bersifat umum ditandai dengan Isim Maușūl yaitu al-ladzi.

d. Pada Surah al-Insān [76]: 3 terdapat lafal syākiran, sasaran ayat ini adalah umum ditandai dengan Isim Maușūl yaitu $m \bar{a}$.

${ }^{40}$ al-Shiddieqy, Ilmu-ilmu Al-Qur'an, h. 18.

${ }^{41}$ al-Qațān, Mabāhīis fì Ulūm Al-Qur ān, h. 109.

${ }^{42}$ M. Quraish Shihab, Kaidah Tafsir, h. 179-183.

${ }^{43} \mathrm{Al}$ - 'Ām al-Istighrāqī adalah bentuk kata yang mencakup segala sesuatu yang dapat dicakupnya tanpa kecuali, sehingga semua disentuh olehnya. Contohnya dalam hal ini, alhamdulillah. Al pada kata al-ḥamd disebut "Al” al-Istighrāq karena segala pujian hanya milik Allah dan untuk Allah. Lihat M. Quraish Shihab, Kaidah Tafsir, h. 180. 
Makna Al-Hamd dan Al-Syukr dalam Tafsir

(Studi Analisis Metode Tafsir Muqarran)

Kemudian ayat-ayat yang mengandung makna khaṣ dalam lafal al-hamd dan alsyukr pada penelitian ini terdapat pada surah-surah sebagai berikut:

1. Ayat-ayat al-hamd yang mengandung makna khaș.

a. Pada Surah Ibrāhīm [14]: 39 terdapat lafal al-ḥamd, sasaran dalam ayat ini adalah pujian Nabi Ibrahim yang dikaruniai seorang anak dalam usianya yang sudah tua bersama Sarah.

b. Pada Surah Āli 'Imrān [3]: 188 terdapat kata yuhmadū, sasaran dalam ayat ini adalah khusus yang ditujukan untuk orang munafik dan para ulama Yahudi dengan Isim Maușūl yaitu al-ladzinna. Namun makna dan maksudnya adalah untuk umum.

2. Ayat-ayat al-syukr yang mengandung makna khas

a. Pada Surah al-Baqarah [2]: 52 terdapat lafal tasykurūn, ayat ini mengandung makna khaṣ karena ayat ini ditujukan untuk Bani Israil.

b. Surah al-Isrā' [17]: 3 ini bersifat khusus karena ditujukan kepada nabi Nuh sebagai hamba yang banyak bersyukur kepada Allah.

c. Pada Surah al-Naml [27]: 40 terdapat lafal syakara-yasykuru sekaligus, sasaran ayat ini adalah nabi Sulaiman. Namun peringatan untuk bersyukur berlaku untuk semua manusia.

\section{PENAFSIRAN AL-ṬABARĪ, AL-QURṬUBĪ DAN IBN KATHĪR ATAS KATA $A L-H A M D$ DAN $A L-S Y U K R$}

Seperti yang telah dijelaskan sebelumnya, penulisan ini akan membahas pemaknaan al-hamd dan al-syukr dalam Al-Qur'an. Namun pembahasannya dibatasi, hanya enam ayat pada kata al-hamd dan tujuh ayat pada kata al-syukr. Karena itu, penulisan ini akan membahas lebih lanjut mengenai pemaknaan kedua kata tersebut menurut penafsiran al-Ṭabarī, al-Qurțubī, dan Ibn Kathīr.

\section{Penafsiran Kata al-Hamd}

Penggunaan kata al-hamd dalam Al-Qur'an ada yang diikuti oleh dhamir dan ada yang tidak. Kata al-hamd yang tidak diikuti dengan dhamir ditemukan ada 38 kali pengulangan pada beberapa ayat, sedangkan yang diikuti dhamir ada 7 ayat serta kata dasar dari al-hamd tanpa diiringi dengan al ada 23 ayat. Berikut akan dibahas beberapa contoh penggunaan kata al-hamd.

\section{Kata al-hamd}

a. Surah al-Fātiḥah [1]: 2

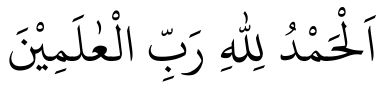

"Segala puji bagi Allah, Tuhan seluruh alam." (QS. Al-Fātiḥah [1]: 2)

Pembahasan ayat ini difokuskan pada tema "Pujian, Allah menyanjung zat-Nya dengan pujian dan mengawali kitab-Nya dengan pujian”. Lafal alhamdulillāh oleh alTabarī diartikan sebagai sebuah kesyukuran yang hanya ditujukan kepada Allah tidak kepada selain-Nya. Baik itu karena kebaikan, nikmat, anugerah, dan segala pemberian 
yang diberikan-Nya kepada makhluk-Nya. ${ }^{44} \mathrm{Hal}$ ini sesuai dengan riwayat Ibn 'Abbās yang menyebutkan bahwa alhamdulillāh artinya bersyukur kepada Allah atas segala nikmat yang diberikan oleh-Nya.

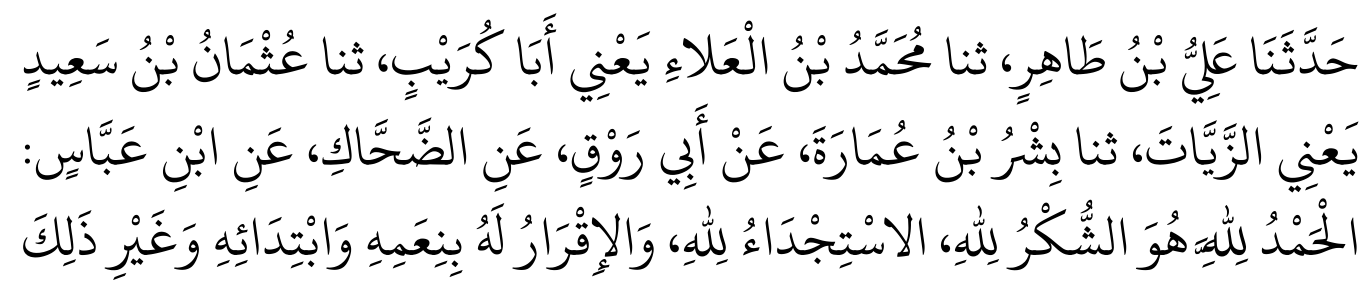

“'Alī ibn Tāhir menceritakan kepada kami, Muhammad ibn al-'Alā', Uthmān ibn Sa'̄̇d menceritakan kepada kami, Basyar ibn 'Imārah menceritakan kepada kami, dari Abū Rauq, dari al-Dahāk, dari ibn 'Abbās, ia berkata: "Alhamdulillāh adalah bersyukur kepada Allah, memohon kepada Allah, dan mengakui segala nikmat, hidayah, ciptaan-Nya, dan selainnya." 45

Al-Ṭabarī juga menjelaskan bahwa al-hamd itu sama dengan al-syukr, merujuk pada kesepakatan para ahli bahasa yang mengatakan tidak salah ketika seseorang mengucapkan "Alhamdulillāh, syukur". Dengan alasan terkadang posisi keduanya saling bertukar, ketika kata alhamdulillāh digunakan untuk mengungkapkan syukur oleh seseorang. Begitu sebaliknya, terkadang kata syukur digunakan untuk mengungkapkan pujian. ${ }^{46}$ Seperti riwayat yang datang dari Ibn 'Abbās yang mengatakan alhamdulillah adalah kalimat syukur.

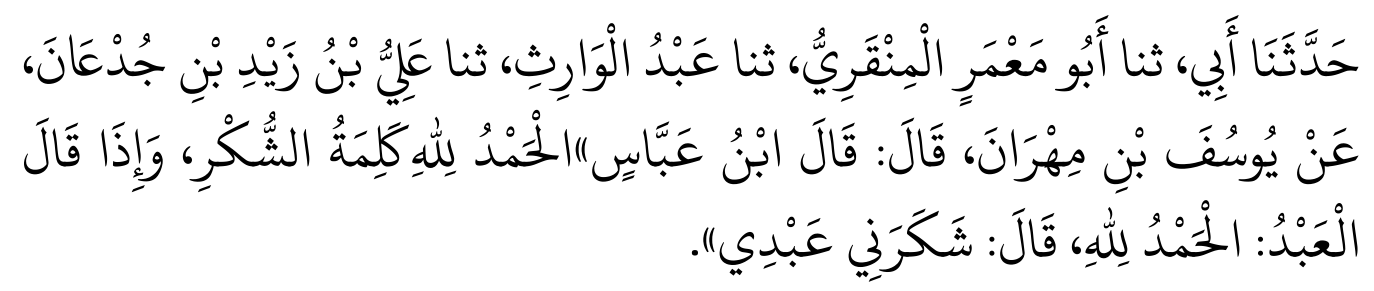

"Bapakku menceritakan kepada kami, Abū Ma'mar al-Minqarī menceritakan kepada kami, 'Abd al-Warith menceritakan kepada kami, 'Alī ibn Zaid ibn Jud'ān menceritakan kepada kami, dari Yūsuf ibn Mihrān berkata, Ibn 'Abbās berkata: Alhamdulillāh adalah kalimat syukur, dan jika seorang hamba mengucapkan alhamdulillāh. Allah berfirman: Hambaku bersyukur kepada-Ku”. ${ }^{47}$

Sedangkan al-Qurțubī memaknai al-ḥamd sebagai sanjungan kepada yang dipuji karena sifat-sifatnya tanpa diiringi kebaikan yang dilakukan olehnya, dengan begitu penggunaan kata al-hamd tidak hanya dikhususkan untuk Allah. Menolak pendapat al-Ṭabarī, ia mengatakan bahwa al-hamd dan al-syukr itu berbeda. Al-syukr adalah sanjungan kepada yang disyukuri disebabkan kebaikannya, jadi kesyukuran ini hanya dikhususkan untuk orang yang telah melakukan kebaikan tersebut. Al-hamd mengandung 3 makna sekaligus, yaitu al-than $\bar{a}$ ' (sanjungan), al-tahmmìd (pujian), dan al-syukr (syukur). Oleh karena itu al-hamd lebih umum daripada $a l$-syukr. ${ }^{48}$

${ }^{44}$ Abū Ja'far Muhammad bin Jarīr al-Ṭabarī, Tafsīr Jāmi' al-Bayān fì Ta'wìl al-Qur 'an, tahqiq. Aḥmad Muḥammad Syākir, J. 1, Cet. I (Beirut: Muassasah al-Risālah, 2000), h. 135.

${ }^{45}$ Ibn Abī Ḥatim al-Rāzì, Tafsīr ibn Abī Hātim, J. 2 (t,t), h. 2.

${ }^{46}$ al-Ṭabarī, Tafsīr Jāmi’ al-Bayān, J. 1, h. 138.

${ }^{47}$ al-Rāzì, Tafsìr ibn Abī Hātim, h. 2.

${ }^{48}$ Abū 'Abdillāh al-Qurțubī, al-Jāmi' li Aḥām al-Qur 'an, taḥqiq. Aḥmad al-Bardūnī dan Ibrāhīm Aṭ̂īsiy, J. 1, Cet. II (al-Qāhirah: Dār al-Kutub al-Misriyah, 1964), h. 131-139. 
Lebih jelas ibn Kathīr menyebutkan bahwa perkataan al-Ṭabarī bahwa al-ḥamd dan alsyukr itu sama berpatokan dengan kalimat al-hamd lillāh syukran, haruslah dipertimbangkan. Karena para ulama kontemporer berpendapat bahwa kedua kata tersebut memiliki makna umum dan khusus, al-hamd lebih umum daripada al-syukr karena kata al-hamd merupakan sanjungan dengan perkataan kepada yang dipuji, dengan sifat-sifatnya yang lazim (tidak terikحدته لفروسيته وحمدته لكرمه (pujian atas sifatnya yang kesatria dan pujian atas kemuliaannya), dan al-hamd disebut lebih khusus karena sekedar ucapan. Sedangkan al-syukr lebih umum dari al-hamd karena dilakukan dengan hati, lisan, serta anggota tubuh, dan dikatakan lebih khusus dari al-hamd karena sebatas sifat-sifat muta'adi (terikat dengan hal lain). Contohnya: "Saya berterima kasih atas kemuliaan dan kebaikannya kepadaku". ${ }^{49}$

Adapun adanya alif dan lam pada kata alhamdulillāh, menurut al-Ṭabarī memiliki makna khusus yakni "segala puji bagi Allah". Hal ini berbeda dengan kata hamdan lillāh yang tidak diiringi dengan alif dan lam, dimaknai "aku memuji Allah" yang berarti tidak sesempurna pujian yang ditujukan untuk Allah, hanya sekedar pujian saja. AlȚabarī sepakat dengan para qari membaca marfu' pada kata al-hamd dan menyalahkan yang membaca nașab, karena apabila marfu' kata al-hamd mengandung makna pujian yang sempurna. ${ }^{50}$ Namun dijelaskan oleh Sibawaih dalam tafsir al-Qurțubī, apabila dal di-rafa-kan pada kata al-hamd. Maka al-hamd bermakna pujian yang berasal dari Allah dan juga seluruh ciptaan-Nya, dan apabila dal dibaca nașab maka bermakna pujian itu hanya berasal dari Allah. ${ }^{51}$

Kata Allāh oleh al-Ṭabarī diartikan sesuai riwayat dari ibn "Abbās yaitu: "Yang di Tuhankan oleh segala sesuatu dan disembah oleh seluruh makhluk". Al-Ṭabarī menerangkan dalam kitabnya, terjadi pembuangan huruf hamzah dan penambahan huruf lam pada lafal Allah yang berawal dari ucapan-ucapan orang Arab yaitu al-ilāh. Selanjutnya kata $r a b$ oleh al-Ṭabarī dimaknai sebagai tuan, seseorang yang shalih, dan juga pemilik. Pemaknaan lengkap pada kata al-hamd lillāh rabb al-'älamìn disesuaikan dengan riwayat dari ibn 'Abbās : "Jibril mendatangi Rasulullah dan berkata, 'Wahai Muhammad, ucapkanlah al-hamd lillāh rabb al-'älamīn. Ucapkanlah segala puji bagi Allah pemilik seluruh makhluk, seluruh langit serta isinya, seluruh bumi serta isinya, yang diketahui dan tidak diketahui. Ketahuilah Muhammad, bahwa Tuhanmu tidak menyerupai suatu apa pun'." ${ }^{2}$ Sama halnya dengan al-Ṭabarī, al-Qurțubī juga memaknai rabb al- 'älamīn sebagai "Tuhan (pemilik) semesta alam". ${ }^{53}$

Sebagai pendukung penjelasan, pembahasan kata al-hamd di awal surah ditemukan tidak hanya pada surah al-Fatihāh, tetapi juga pada surah al-An'ām [6]: 1, al-Kahfi [18]: 1, Saba' [34]: 1, dan Fāțir [35]: 1. Penggunaan kata alhamdulillāh pada awal kalimat surat ini tentunya termasuk sebagai perwujudan dari rasa syukur yang Allah berikan. Pada surah al-An'ām [6]: 1 digambarkan nikmat Allah berupa penciptaan manusia dengan potensi yang dimilikinya, kemudian pada surah al-Kahfi [18]: 1 nikmat itu

${ }^{49}$ Abū al-Fidā' Ismā'̄il bin'Umar bin Kas̄īr al-Quraisȳ̄ al-Dimasyqī, Tafsīr al-Qur'ān al- 'Azīm, tahqiq. Sāmī bin Muḥammad Salāmah, J. 1, Cet. 2 (Dār Ṭayyibah, 1420), h. 128.

${ }^{50}$ al-Ṭabarī, Tafsīr Jāmi’ al-Bayān, J. 1, h. 138.

${ }^{51}$ al-Qurțubī, al-Jāmi 'li Aḥkām Al-Qur 'an, J. 1, h. 135.

${ }^{52}$ al-Ṭabarī, Tafsìr Jāmi’ al-Bayān, J. 1, h. 141-146.

${ }^{53}$ al-Qurțub̄̄, al-Jāmi ‘li Aḥkām Al-Qur `an, J. 1, h. 136-139. 
disempurnakan oleh Allah dengan pemeliharaan-Nya kepada makhluk-Nya di dunia ini baik material maupun non material. Pada surah Saba' [34]: 1 dijelaskan tentang nikmatnikmat akhirat yang akan diperoleh hamba-Nya, dan surah Fāțir [35]: 1 menerangkan nikmat yang akan diterima setelah hari kebangkitan nanti oleh hamba-Nya. Kalimat al-hamd lillāh pada awal surah tersebut diindikasikan sebagai ungkapan syukur atas nikmat yang Allah berikan, serta Allah memberitahukan kepada manusia cara untuk memuji dan mensyukuri nikmat yang telah diberikan-Nya.

b. Surah Ibrāhīm [14]: 39

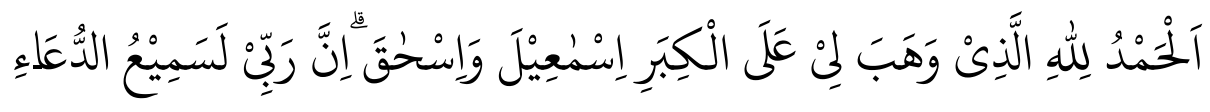

"Segala puji bagi Allah yang telah menganugerahkan kepadaku di hari tua(ku) Ismail dan Ishak. Sungguh, Tuhanku benar-benar Maha Mendengar (memperkenankan) doa." (QS. Ibrahim [14]: 39)

Ayat ini diletakkan pada tema, "Alhamdulillah sebagai ucapan syukur". Ayat ini menerangkan rasa syukur Nabi Ibrāhīm kepada Allah atas karunia anak yang didapatkan dengan mengucapkan pujian, padahal saat itu Nabi Ibrāhīm dan istrinya telah lanjut usia yang tidak mungkin bagi mereka akan memiliki seorang anak. Namun Allah memberinya nikmat berupa anak setelah ia meminta kepada-Nya, hal ini menegaskan bahwa Allah memenuhi permohonan orang-orang yang berdo'a kepada-Nya. ${ }^{54}$

Al-Ṭabarī menjelaskan hal yang sama pada ayat ini, yang mana Ibrāhīm memuji Allah karena telah memberikan rezeki berupa anak yang diberi nama Ismā'̄̄l dan Ishāq saat usianya sudah tua. Serta memanjatkan puji dan syukur kepada Allah karena telah mengabulkan doa-doanya yang lain, salah satunya yaitu: "Jadikanlah negeri ini (Makkah), negeri yang aman dan jauhkanlah aku beserta anak cucuku dari menyembah berhala-berhala." ${ }_{55}$

Selain dari ayat ini, ada beberapa ayat yang sama-sama mengindikasikan bahwa alhamdulillāh sebagai bentuk pujian (al-hamd) merupakan ungkapan syukur atas nikmat atau kebaikan yang didapatkan melalui lisan yaitu surah al-Mu'minūn [23]: 28 tentang perintah Allah kepada Nabi Nuh, surah al-Naml [27]: 15 tentang Nabi Daud dan Nabi Sulaiman. Kemudian pada surah al-Isrā' [17]: 111 Allah berfirman kepada nabi-nabiNya untuk mengucapkan alhamdulillāh, surah Fāṭir [35]: 34 tentang penghuni surga, dan juga surah Yūnus [10]: 10 bahwasanya alhamdulillāh merupakan penutup doa.

\section{Kata bihamdika}

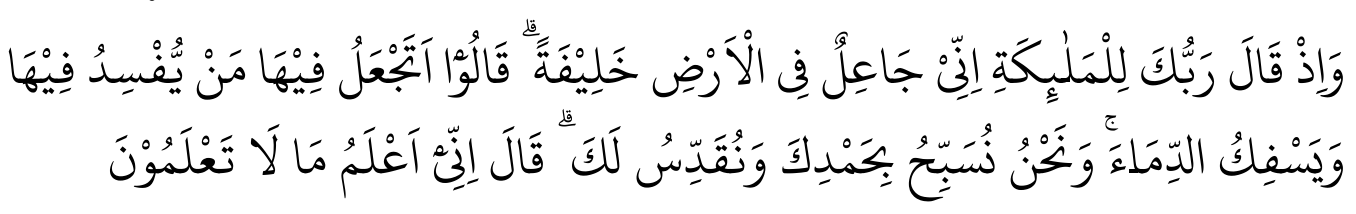

"Dan (ingatlah) ketika Tuhanmu berfirman kepada para malaikat, "Aku hendak menjadikan khalifah di bumi." Mereka berkata, "Apakah Engkau hendak menjadikan orang yang merusak dan menumpahkan darah di sana, sedangkan kami bertasbih memuji-Mu dan menyucikan nama-Mu?" Dia berfirman,

\footnotetext{
${ }^{54}$ al-Qurțubī, al-Jāmi ‘ li Aḥkām Al-Qur `an, J. 9, h. 375. Lihat juga Abū al-Fidā’ Ismā’̄il, Tafsīr Al-Qur'ān al-'Az̄ìm, J. 4, h. 514.

${ }^{55}$ al-Ṭabarī, Tafsīr Jāmi' al-Bayān, J. 17, h. 27.
} 
Makna Al-Hamd dan Al-Syukr dalam Tafsir

(Studi Analisis Metode Tafsir Muqarran)

"Sungguh, Aku mengetahui apa yang tidak kamu ketahui.” (QS. Al-Baqarah [2]: 30)

Pembahasan ayat ini mengacu pada pertanyaan malaikat "mengapa Allah menciptakan orang yang akan merusak sedangkan malaikat selalu bertasbih memuji Allah", seakan-akan malaikat berkata mengapa Engkau ciptakan khalifah di muka bumi dengan sifatnya yang merusak, sedangkan kami yang selalu bertasbih dan memuji-Mu?. (maksudnya adalah selalu bertasbih dan menyucikan Allah dari dugaan-dugaan orang musyrik dan memuji seluruh sifat yang ada pada Allah) Para malaikat menduga bahwa seluruh Bani Adam akan menumpahkan darah dan membuat kerusakan di bumi, mereka tidak mengetahui bahwa di antara Bani Adam akan ada yang menjadi Nabi, orang saleh, dan wali. Namun hal ini bukan untuk mengingkari apa yang Allah firmankan, ayat ini ditujukan kepada malaikat yang mana memperingatkan untuk mensyukuri penciptaannya dari cahaya namun tidak untuk menjadikannya riya' seolah-olah lebih sempurna dari penciptaan manusia. Ibnu Kathīr menjelaskan bahwa Ibnu Juraij berkata, sesungguhnya para malaikat itu berkata menurut apa yang telah diberitakan Allah terlebih dahulu. Perkataan malaikat tersebut bukanlah sebagai bantahan kepada Allah melainkan meminta informasi dan mencari tahu hikmah diciptakannya keturunan nabi Adam, karena malaikat diberikan sifat sebagai makhluk yang tidak menanyakan sesuatu yang tidak diizinkan Allah. ${ }^{56}$

Al-Qurțubī menjelaskan kata $i d z$ yang ada dalam kata pertama pada ayat ini, kata $i d z$ dan $i d z a$ merupakan dua huruf tauqīt (yang menunjukkan waktu). Idz yang dipakai untuk masa yang telah lalu, tetapi $i d z$ menjadi bermakna masa yang telah lampau jika diiringi fi'il muḍ̂ari' (kata kerja masa akan datang). Sedangkan idza untuk masa yang akan datang, tetapi jika diikuti fi'il mā di, menjadi bermakna masa akan datang. Ada yang berpendapat bahwa $i d z$ pada ayat ini kembali pada firman Allah ' $u$ 'budu rabbakum al-ladzī khalaqakum (sembahlah Tuhanmu yang telah menciptakanmu), karena itu dimaknai: Tuhanmu yang telah menciptakanmu ketika Tuhanmu berfirman kepada malaikat. Al-Ṭabarī memaknai sama dalam ayat ini, hanya saja ia menjelaskan bahwa sebagian ahli bahasa dari Bashrah mengatakan arti wa idz qāla rabbuka (adalah Tuhanmu berkata) dengan menghilangkan $i d z$ yang hanya sebagai tambahan, namun ia tidak setuju dengan penghapusan itu karena akan merubah makna yang mana Allah berdialog dengan orang-orang pada ayat tersebut.

Dijelaskan dalam ayat ini bahwa Allah akan menciptakan khalifah (pengganti orang sebelumnya) pada ayat ini tidak untuk berdialog dengan malaikat, melainkan untuk mengetahui apa yang dirasakan mereka selain dari ketaatannya kepada Allah dan juga menguji mereka dengan alasan menjelaskan bahwa pengetahuan mereka itu terbatas. Adapun penggunaan kata khaliffah di sini menjadi sebuah pemahaman para malaikat bahwa anak cucu Adam akan berbuat kerusakan, karena kata khalīfah adalah al-iṣlāh (memperbaiki) dan meninggalkan perbuatan yang merusak.

Sedangkan kata tasbih pada ayat ini dalam bahasa Arab diartikan sebagai bentuk penyucian dari yang buruk dalam ungkapan pengagungan, namun ada perbedaan pendapat pada tasbih para malaikat sebagai shalat atau mengeraskan bacaan zikir. Sedangkan kata bihamdika merupakan pernyataan terpisah, dan dijadikan sebagai pengakuan mereka bertasbih, memuji Allah dan juga menyucikan-Nya (wa nuqaddisu

${ }^{56}$ Abū al-Fidā' Ismā'īl, Tafsīr Al-Qur'ān al- 'Ażìm, J. 1, h. 216-221. 
laka), jadi artinya adalah "kami menyucikan-Mu dari apa yang dinisbatkan orang musyrik kepada-Mu, kami shalat untuk-Mu, dan kami menisbatkan-Mu kepada sifat-sifat yang suci serta terpuji. Karena shalat menurut al-Qurțubī mengandung pengagungan, penyucian dan tasbih. Kemudian Allah menjelaskan pada akhir ayat ini bahwa Allah mengetahui apa yang telah terjadi, apa yang akan terjadi, dan apa yang terus terjadi. Allah mengetahui kesombongan yang dirahasiakan iblis dalam dirinya, sedangkan malaikat tidak mengetahuinya. ${ }^{57}$

\section{Kata yahmadī}

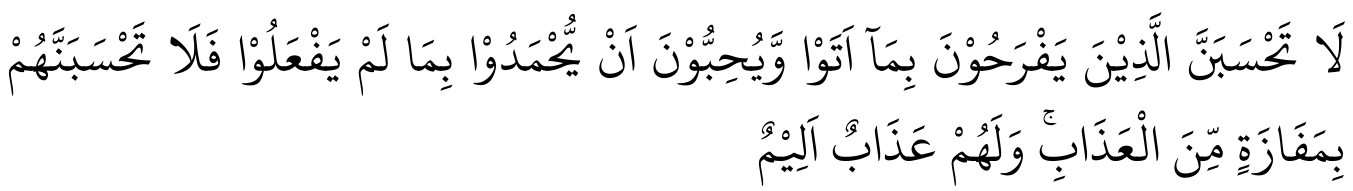

"Jangan sekali-kali kamu mengira bahwa orang yang gembira dengan apa yang telah mereka kerjakan dan mereka suka dipuji atas perbuatan yang tidak mereka lakukan, jangan sekali-kali kamu mengira bahwa mereka akan lolos dari azab. Mereka akan mendapat azab yang pedih.” (QS. Ali 'Imran [3]: 188)

Ayat ini turun kepada orang-orang munafik yang tidak mau ikut berperang dengan selalu mencari-cari alasan, sedangkan ibnu 'Abbās menyebutkan bahwa ayat ini turun kepada ahli kitab yang ditanya oleh Rasulullah namun mereka menyembunyikan jawabannya dan memberikan jawaban yang tidak sesuai. ${ }^{58}$ Ayat ini juga menunjukkan pembahasan tentang "manusia yang suka dipuji”, Allah mencela dan mengancam ahli kitab yang telah diambil janjinya oleh Allah untuk beriman kepada Nabi Muhammad. Apabila Allah mengutus rasul mereka mengikutinya, namun menyembunyikan cerita Nabi Muhammad dan menggantikan kebaikan dunia dan akhirat yang dijanjikan dengan imbalan duniawi yang hina dan juga orang-orang yang riya' dan menceritakan kekayaan yang tidak dipunyainya. ${ }^{59}$ Adapun pemaknaan senang dipuji di sini berbeda-beda, ada yang berpendapat bahwa mereka yang bergembira adalah orang-orang munafik yang tidak ikut berperang bersama Rasulullah dengan berbagai alasan, para ulama Yahudi yang telah menyesatkan manusia, mendustakan Rasulullah. Kemudian mengharapkan pujian, bahagia atas pujian dari hal yang sama sekali tidak mereka lakukan, bangga disebut sebagai ahli ilmu, senang ketika disebut sebagai ahli shalat dan puasa, dan senang ketika dipuji karena merubah kitabullah. Al-Ṭabarī menambahkan bahwa objek pada ayat ini adalah ahli kitab, yang menyembunyikan kebenaran tentang nabi Muhammad pada kitab-kitab mereka dan menyangka akan selamat dari siksa Allah. ${ }^{60}$

Sedangkan al-Qurțubī menjelaskan bahwa maksud ayat ini adalah semua orang memiliki kewajiban berjihad, jadi jangan mengira orang yang hanya berdiam diri dan meninggalkan jihad akan terhindar dari siksa Allah. Adapun yang dimaksud dengan orang yang bergembira dan suka dipuji di atas, pemaknaannya sama dengan al-Ṭabarī ditujukan untuk dua kelompok yakni kelompok orang-orang yang munafik dan para

${ }^{57}$ al-Qurțubī, al-Jāmi ' li Ahkām Al-Qur 'an, J. 1, h. 261-278. lihat juga al-Ṭabarī, Tafsīr Jāmi’ al-Bayān, J. 1, h. 439-479.

58 Jalāluddīn al-Suyuțī, Asbāb al-Nuzūl: Sebab Turunnya Ayat Al-Qur 'an, terj. Tim Abdul Hayyie, Cet. I (Jakarta: Gema Insani, 2008), h. 146-148.

${ }^{59}$ Abū al-Fidā' Ismā'îl, Tafsìr al-Qur'ān al- 'Ażìm, J. 2, h. 180-181.

${ }^{60}$ al-Ṭabarī, Tafsīr Jāmi' al-Bayān, J. 7, h. 465-472. 
Makna Al-Hamd dan Al-Syukr dalam Tafsir

(Studi Analisis Metode Tafsir Muqarran)

ulama dari kaum Yahudi. ${ }^{61}$ Jelas pada ayat ini Allah memperingatkan hamba-Nya agar tidak berbuat riya atau melakukan sesuatu yang ingin dipuji, karena riya mendatangkan siksa.

\section{Penafsiran Kata al-Syukr}

Begitu juga dengan kata al-syukr ada yang diikuti oleh dam $\overline{\boldsymbol{\imath}}$ r dan tidak, baik berbentuk mufrad, muthanna, maupun jama'. Kata syukr yang tidak diikuti dengan dhamir ditemukan ada 29 kali pengulangan pada beberapa ayat, sedangkan yang diikuti dhamir maupun berbentuk jama' ada 46 ayat. Berikut akan dibahas beberapa contoh penggunaan kata al-syukr.

\section{Kata tasykurūn}

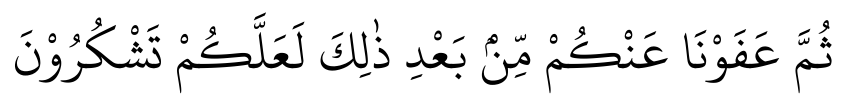

"Kemudian Kami memaafkan kamu setelah itu, agar kamu bersyukur.” (QS. AlBaqarah [2]: 52) ${ }^{62}$

Ayat ini menerangkan bahwa Allah memberikan nikmat-Nya yaitu pengampunan untuk hamba-Nya dan tidak menyiksa mereka, setelah mereka melakukan kekafiran dan menyekutukan Allah dengan menyembah seekor anak lembu setelah nabi Musa pergi menuju miqat Rabbnya tatkala menuntaskan lamanya perjanjian 40 hari setelah mereka selamat dari Fir'aun dan lautan. Agar mereka bersyukur kepada Allah atas ampunan yang telah Allah berikan. ${ }^{63}$

Al-Qurțubī menafsirkan hal yang sama dalam tafsirnya, namun ia juga menjelaskan tentang penggunaan kata 'afw (maaf) pada ayat ini berbeda dengan al-ghufrān (ampunan). Karena kata 'afw di sini bermakna Allah memberikan maaf kepada hambaNya, maaf ini terkadang diberikan sebelum atau setelah didahului hukuman yang bisa disebut sebagai penghapusan dosa. Sedangkan al-ghufrān adalah ampunan yang tidak adanya hukuman di dalamnya. ${ }^{64}$ Sesuai dengan riwayat dari Abū Aliyah:

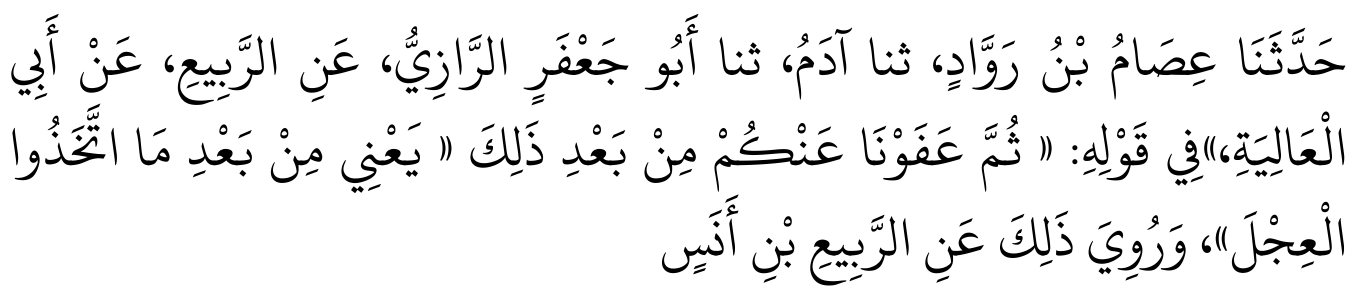

“'Ișām bin Rawwād menceritakan kepada kami, Abū Ja'far al-Rāzī menceritakan

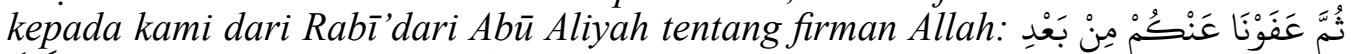
ذلِكَ 'Kemudian Kami memaafkan kamu setelah itu, agar kamu bersyukur, 'maksudnya sesudah kalian menjadikan anak lembu itu sebagai sesembahan." Hadits ini diriwayatkan dari Rabī' bin Anas. ${ }^{65}$

Jadi dapat disimpulkan bahwasanya, Allah memberikan ampunan bagi mereka yang telah menyekutukan Allah agar mereka dapat mensyukuri nikmat ampunan yang telah

${ }^{61}$ al-Qurțubī, al-Jāmi` li Aḥkām al-Qur `an, J. 4, h. 306-307.

${ }^{62}$ Kementerian Agama RI, Al-Qur'ān Kemenag.

${ }^{63}$ al-Ṭabarī, Tafsìr Jāmi' al-Bayān, J. 2, h. 69. Lihat juga Abū al-Fidā' Ismā'îl, Tafsīr Al-Qur'ān al-'Azìm, J. 1, h. 261.

${ }^{64}$ al-Qurțubī, al-Jāmi`li Aḥkām Al-Qur`an, J. 1, h. 397.

${ }^{65}$ al-Rāzì, Tafsīr ibn Abī Hātim, J. 1, h. 134. 
diberikan. Adapun ampunan ini diikuti dengan hukuman baik sebelum atau setelah ampunan itu diberikan. Selanjutnya ayat-ayat yang juga berisi seruan kepada manusia agar bersyukur atas nikmat yang Allah berikan adalah surah al-Baqarah [2]: 56,172, dan 185, surah al-Mā'idah [5]: 6 dan 89, surah al-A'rāf [7]: 58 dan 144, surah al-Anfāl [8]: 26, surah Ibrāhīm [14]: 5 dan 37, surah al-Nahl [16]: 114, surah al-Anbiya' [21]: 80, surah al-Hajj [22]: 36, surah al-'Ankabūt [29]: 17, surah Luqmān [31]: 31, surah Saba' [34]: 19 dan 15, surah Fāṭir [35]: 12, surah al-Zumar [39]: 66, surah al-Syūrā [42]: 33, dan surah al-Jāthiah [45]: 12.

\section{Kata al-syākirīn}

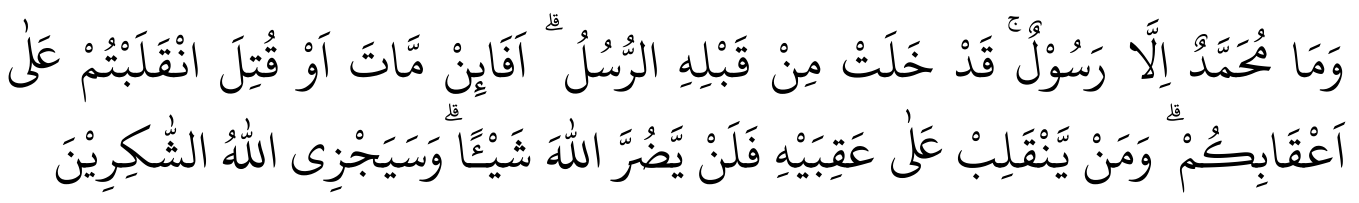

"Dan Muhammad hanyalah seorang Rasul; sebelumnya telah berlalu beberapa rasul. Apakah jika dia wafat atau dibunuh kamu berbalik ke belakang (murtad)? Barangsiapa berbalik ke belakang, maka ia tidak akan merugikan Allah sedikit pun. Allah akan memberi balasan kepada orang yang bersyukur.” (QS. Ali 'Imran [3]: 144)

Pembahasan ayat ini difokuskan pada tema "balasan Allah kepada orang yang bersyukur". Pada ayat ini, selain kata al-Syukr ditemukan juga kata hamd dengan redaksinya yaitu Muhammad. Ayat ini turun ketika perang Uhud, saat kaum muslimin putus asa dan mundur ketika datang berita kematian Rasulullah Saw kepada mereka. Sesuai dengan riwayat:

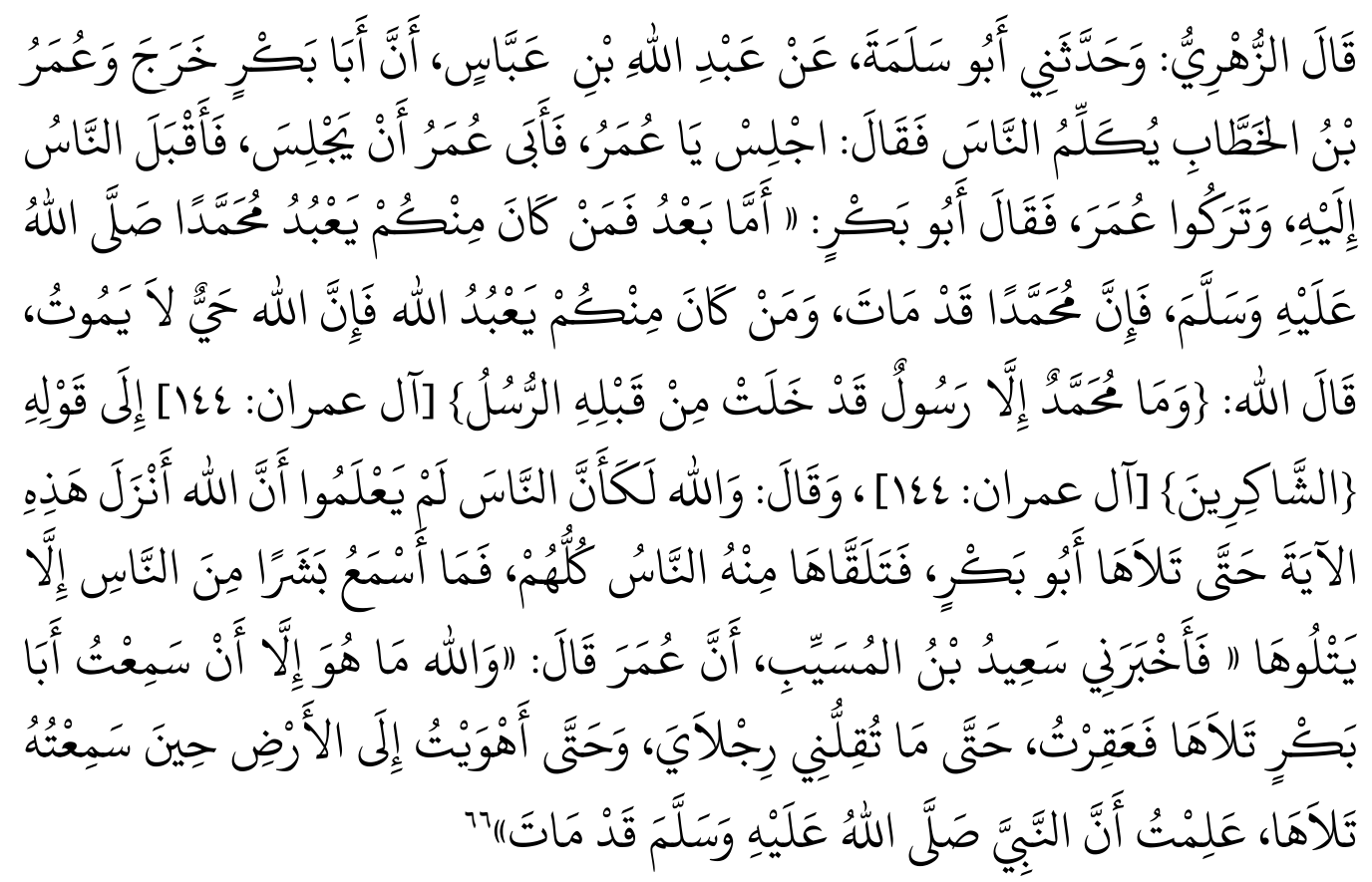

"al-Zuhrī berkata: Abū Salamah menceritakan kepadaku dari 'Abdillah bin 'Abbās, bahwa Abū Bakar pergi sementara 'Umar bin Khațāb berkata kepada orang-orang. Abū Bakar berkata: duduklah wahai 'Umar, 'Umar menolak untuk

${ }^{66}$ Muḥammad bin Ismā'̄il Abū 'Abdillāh al-Bukhārī, Șaḥịh al-Bukhārī, tahqiq. Muḥammad Zahīr bin Nāṣir, J. 5, Cet. I (Mekakh: Dār Ṭauq al-Najah, 1442), h. 6. 
duduk, jadi orang-orang datang kepadanya dan meninggalkan 'Umar. Abū Bakar berkata: Amma ba'du. Barangsiapa di antara kalian yang menyembah nabi Muhammad Saw, maka sesungguhnya nabi Muhammad telah meninggal. Dan barangsiapa dari kalian yang menyembah Allah, maka sesungguhnya Allah Maha Hidup dan Tidak Mati. Maka Allah berfirman "Dan Muhammad hanyalah seorang Rasul; sebelumnya telah berlalu beberapa rasul", 'Umar berkata: Demi Allah, seolah-olah tidak ada orang yang tahu Allah menurunkan ayat ini sampai Abū Bakar membacakannya, maka semua orang membaca ayat itu dari Abū Bakar. Tidak ada seorang pun yang menyimaknya, melainkan dia membacanya. Sa'īd bin al-Musayyib mengabarkan kepadaku bahwa 'Umar berkata: Demi Allah Aku tidak mendengar selain Abū Bakar yang membacanya dan aku tidak berdaya, hingga aku keringatan dan kedua kakiku lemas, hingga aku jatuh ke tanah ketika aku mendengarnya, aku mengetahui bahwa nabi Muhammad telah meninggal."

Lalu lafal wa sayajzi al-Allāh al-syākirīn beberapa pendapat menyebutkan bahwa yang dimaksud adalah Abu Bakar dan para sahabatnya yang tetap berpegang teguh pada agama yang dibawa oleh Rasulullah, sesuai riwayat Ibn Jarīr dari Alī bin Abī Ṭālib. Alī berkata bahwa Abu Bakar adalah pemimpin orang-orang yang bersyukur, pemimpin para kekasih Allah. ${ }^{67}$

Al-Ṭabarī menerangkan bahwa Allah menekankan pada ayat ini, jika nabi Muhammad adalah seorang rasul yang juga akan menemui ajalnya seperti nabi yang lainnya. Lalu Allah mencela para sahabat Rasulullah dan kaum muslim yang telah berputus asa setelah mendengar berita kematian nabi Muhammad, serta mencela sebagian dari mereka yang mundur dari medan perang dan kembali kepada kekufuran. Mereka yang kembali kepada kekufuran sama sekali tidak merugikan Allah melainkan diri mereka sendiri, dan Allah akan memberikan balasan bagi orang-orang yang bersyukur atas hidayah dan taufik dari Allah, melaksanakan ketaatan, berperang untuk mempertahankan agamanya dan tidak mundur lantaran musibah, tetap memegang teguh agama Rasulullah baik masih hidup maupun meninggal. ${ }^{68}$

Al-Qurțubī menjelaskan hal yang sama, bahwa ayat ini diturunkan karena mundurnya kaum muslimin dari perang Uhud. Selain itu, dalam ayat ini Allah memberitahukan kepada hamba-Nya bahwa para utusan Allah tidak akan selalu bersama kaumnya. Karena itu, suatu kaum wajib memegang teguh tauhidnya kepada Allah meski utusannya telah wafat. Namun mereka yang kembali kufur sama sekali tidak merugikan Allah. Kemudian Allah juga memuliakan nabi dengan penyebutan nama yang diambil dari nama-Nya, yakni Muhammad dan Ahmmad. Ayat ini menjadi dalil keteguhan sahabat Abu Bakr saat semuanya dilanda kegelisahan dan putus asa mendengar berita kematian Rasulullah, yang pada saat itu Abu Bakar tampil membacakan ayat ini untuk menghentikan kekacauan. Selanjutnya wa sayajzillāh al-syakirīn, al-Qurțubī menerangkan yang dimaksud orang-orang yang bersyukur mereka adalah yang sabar, tetap berjihad dan gugur sebagai syahid. Diletakkannya lafal tersebut setelah falan yadurru al-Allāh syai' $\bar{a}$ untuk mengisyaratkan hubungan antara ancaman dan janji Allah. ${ }^{69}$

67 'Abd al-Rahman bin Abī Bakar Jalāl al-Dīn al-Suyuțī, al-Dur al-Mansīur fì al-Ta'wīl bi al$M a ' s \bar{u} r$, J. 2 (t,t), h. 450.

${ }^{68}$ al-Ṭabarī, Tafsīr Jāmi' al-Bayān, J. 7, h. 251-259. Lihat juga Abū al-Fidā' Ismā'īl, Tafsīr AlQur'ān al- 'Azìm, J. 2, h. 128-129.

${ }^{69}$ al-Qurțub̄̄, al-Jāmi ‘ li Ahkā̄m Al-Qur `an, J. 4, h. 221-226. 
Ada beberapa ayat-ayat yang menjadi pendukung pembahasan tema ayat ini, yaitu surah Āli 'Imrān [3]: 123 dan 145, surah al-An' ām [6]: 53, surah Ibrāhīm [14]: 7, surah al-Furqān [25]: 62, surah al-Qașaș [28]: 73, surah al-Rūm [30]: 46, surah Fāṭir [35]: 30, surah al-Zumar [39]: 7, dan surah al-Qamar [54]: 34-35.

\section{Kata syakūran}

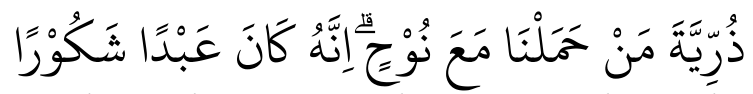

“(Wahai) keturunan orang yang Kami bawa bersama Nuh. Sesungguhnya dia (Nuh) adalah hamba (Allah) yang banyak bersyukur.” (QS. al-Isrā' [17]: 3) $)^{70}$

Pembahasan ayat ini terletak pada tema, "hamba yang banyak bersyukur". Pada ayat ini nabi Nuh disebut sebagai hamba yang banyak bersyukur atas nikmat yang Allah berikan, sesuai dengan riwayat dari Abū 'Uthmān:

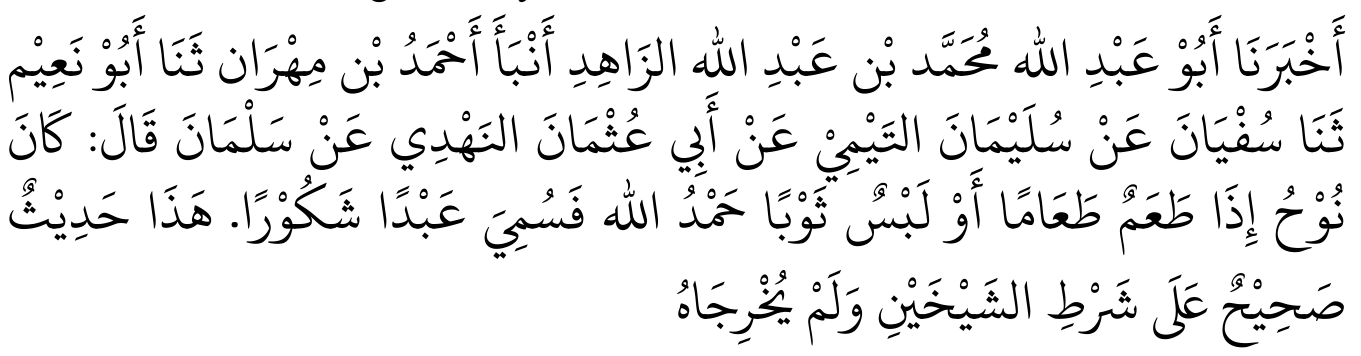

"Abū 'Abdillāh Muhammad bin 'Abdillāh al-Zāhid menceritakan kepada kami, Ahmad bin Mihrān menceritakan kepada kami, Abū Na'țm menceritakan kepada kami, Sufyan menceritakan kepada kami, dari Sulaimān al-Taimī dari Abū 'Uthmān al-Nahdī dari Salmān berkata: 'Apabila Nuh memakan makanan atau memakai pakaian, maka ia memuji Allah. Oleh karena itu, ia dipanggil hamba yang banyak bersyukur'.'"71

Al-Ṭabarī menjelaskan ayat ini dengan terlebih dahulu menyebutkan ayat sebelumnya, anak cucu di sini disebut sebagai anak cucu Musa. Namun al-Ṭabarī menerangkan kembali, bahwa anak cucu yang dimaksud adalah semua manusia yang diberikannya firman Allah. Baik itu orang Arab maupun non-Arab, baik bani Israil maupun tidak, karena semua acak cucu di bumi ini berasal dari orang-orang yang bersama nabi Nuh dalam bahteranya. Adapun disebutnya nabi Nuh sebagai hamba yang banyak bersyukur oleh Allah, ada beberapa pendapat. Ada yang berpendapat karena nabi Nuh selalu memuji Allah ketika ia memakan makanannya, ketika minum, memakai pakaiannya baik baru maupun tidak, ketika membuang air kecil, ketika memakai sendalnya, dan ketika ia buang hajat. ${ }^{72}$

Al-Qurțubī menerangkan yang sama dalam ayat ini, menurutnya ayat ini merupakan bentuk kalimat panggilan kepada anak cucu di bumi yang berhujjah dengan al-Qur`an dengan menekankan kepada mereka untuk tidak syirik. Anak cucu di sini juga disebut sebagai Musa dan kaumnya dari bani Israil, dan disebut anak cucu Nuh yakni hamba yang banyak bersyukur. Karena itu, manusia sangat layak mengikutinya bukan nenek moyang yang jahil. ${ }^{73}$ Ibn Kathīr menyebutkan asal ayat ini adalah, wahai keturunan

\footnotetext{
${ }^{70}$ Kementerian Agama RI, al-Qur`ān Kemenag.

${ }^{71}$ Al-Imām al-Hākim Abū 'Abdillāh Muhammad, ta'līq. Al-Imām al-Zạabī Syams al-Dīn Abū 'Abdillāh Muḥammad, Al-Mustadrak 'alā al-Ṣahịhain, J. 3 (t.t), h. 206.

72 al-Ṭabarī, Tafsìr Jāmi’ al-Bayān, J. 17, h. 353-355.

${ }^{73}$ al-Qurțubī, al-Jāmi ‘ li Ahkēm Al-Qur`an, J. 10, h. 213.
} 
orang yang telah kami selamatkan lalu kami muatkan bersama Nabi Nuh di atas bahtera. (keturunan diserupakan dengan nenek moyang). Disebutkan bahwa nikmat Allah atas mereka adalah diutusnya Nabi Muhammad, sedangkan Nabi Nuh disebut sebagai hamba yang banyak bersyukur karena selalu memuji Allah ketika makan dan minum. ${ }^{74}$ Pada ayat sebelumnya telah disebutkan jika memenuhi kewajiban bersyukur itu tidaklah mudah tanpa pertolongan Allah, sehingga Allah dalam ayat-Nya hanya memuji dua hamba-Nya salah satunya Nabi Nuh.

\section{Kata syakara dan yasykuru}

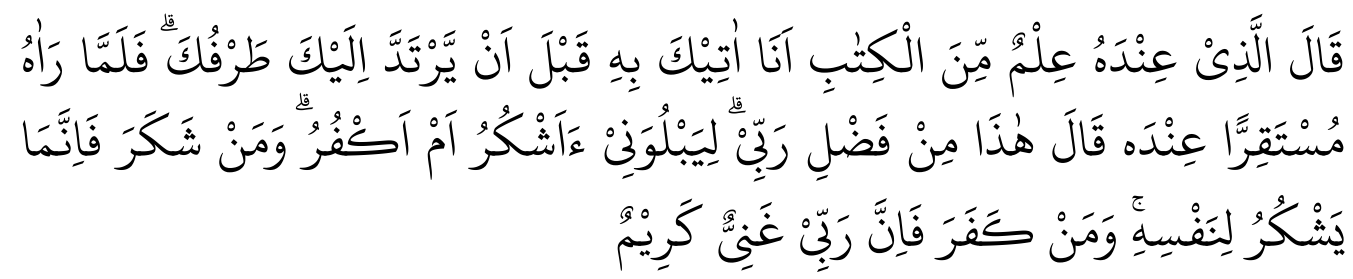

"Seorang yang mempunyai ilmu dari Kitab berkata, "Aku akan membawa singgasana itu kepadamu sebelum matamu berkedip." Maka ketika dia (Sulaiman) melihat singgasana itu terletak di hadapannya, dia pun berkata, "Ini termasuk karunia Tuhanku untuk mengujiku, apakah aku bersyukur atau mengingkari (nikmat-Nya). Barangsiapa bersyukur, maka sesungguhnya dia bersyukur untuk (kebaikan) dirinya sendiri, dan barangsiapa ingkar, maka sesungguhnya Tuhanku Mahakaya, Mahamulia." (QS. an-Naml [27]: 40) 75 $^{75}$

Pembahasan ayat ini terfokus pada tema "apa yang diperbuat oleh manusia apakah dia bersyukur atau ingkar, akan ia petik sendiri hasilnya". Adapun ayat ini dari surah alNaml ayat 38-40 menceritakan tentang kisah nabi Sulaiman as. yang akan menaklukkan kepemimpinan ratu Saba', dimulai ketika hud-hud datang membawa kabar bahwa ratu Saba' memiliki singgasana yang agung dan nabi Sulaiman menginginkan siapa pun yang bisa memindahkan singgasana ratu Saba' lebih cepat dari sebelum ia berdiri. Kemudian ada seorang yang mempunyai ilmu kitab berkata, ia bisa memindahkan singgasana tersebut sebelum nabi Sulaiman berkedip. Para mufasir berbeda pendapat dengan orang yang dimaksud, namun kebanyakan mengatakan dia adalah Așif bin Barkhaya seorang dari Bani Israil yang dapat dipercaya. Al-Qurțubī mengatakan ada satu riwayat yang bagus dari ibn Ațiyah, bahwa yang dimaksud seorang itu adalah nabi Sulaiman sendiri dan perkataannya itu untuk merendahkan Ifrit dengan berdalil pada perkataan nabi Sulaiman yakni hadzā min fạ̣li rabbi "Ini termasuk karunia Tuhanku”. Setelah singgasana itu berpindah, kemudian nabi Sulaiman berkata hadzā min fạlli rabbī, liyabluwanī a-asykuru am akfur maksudnya adalah pertolongan dan kemenangan ini disebabkan oleh Allah untuk menguji nabi Sulaiman akankah menjadi hamba yang bersyukur atas nikmat Allah atau kufur terhadap nikmat-Nya. Adapun maksud wa man syakara fainnamā yasykuru linafsih, wa man kafara fainna rabbi ghaniyyun karim adalah apa yang dipilih oleh seorang hamba, apakah ia akan memilih bersyukur ataupun kufur semuanya tetap kembali kepada dirinya sendiri. ${ }^{76}$

Al-Ṭabarī dalam penafsiran ayat ini berpendapat yang sama, namun pada kata liyabluwan̄ a-asykuru am akfur ia berkata maksudnya adalah Allah mengujinya

\footnotetext{
${ }^{74}$ Abū al-Fidā' Ismā'īl, Tafsīr Al-Qur'ān al- 'Ażìm, J. 5, h. 46.

${ }^{75}$ Kementerian Agama RI, al-Qur 'ān Kemenag.

${ }^{76}$ al-Qurțubī, al-Jāmi ' li Aḥkām Al-Qur 'an, J. 13, h. 205-206.
} 
apakah ia menjadi hamba yang bersyukur karena singgasana ratu Saba' yang telah berpindah atas karunia Allah. Ataukah ia akan menjadi kufur karena tidak adanya orang yang akan menandinginya. Adapun kata wa man syakara fainnamā yasykuru linafsih oleh al-Ṭabarī dimaknai, ketika seorang hamba bersyukur atas segala nikmat yang Allah berikan, maka tidak lain dia hanyalah mensyukuri keuntungannya sendiri. Allah menyeru hamba-Nya untuk bersyukur bukan karena Allah berhajat kepada hamba-Nya, melainkan syukurnya seorang hamba akan bermanfaat bagi hamba itu sendiri. Sedangkan kata wa man kafara fainna rabbi ghaniyyun karim dimaknai jika seorang hamba tidak bersyukur atas nikmat yang Allah berikan dan mengingkarinya, sesungguhnya Allah tidak butuh atas syukurnya itu tetapi juga tidak memberikan kerugian atas ketidaksyukuran hamba-Nya. ${ }^{77}$

Ibn Kathīr menyebutkan dinukil dari Ibn Abbas bahwa orang yang mempunyai ilmu dari al-kitab itu bernama Ashif orang yang jujur dan mengetahui nama Allah, sekretaris Nabi Sulaiman. Namun ada pula yang mengatakan bahwa itu adalah malaikat Jibril a.s, malaikat yang diperbantukan kepada Nabi Sulaiman. Maka ketika Nabi Sulaiman belum sadar, singgasana tersebut sudah di depannya. Hal tersebut merupakan sebagian nikmat yang dianugerahkan untuk menguji Nabi Sulaiman, apakah ia akan bersyukur atau mengingkarinya. Karena jika manusia ingkar atas nikmat Allah, Allah tidak bergantung kepada siapa pun, tidak membutuhkan hamba dan penghambaannya. ${ }^{78}$ Bersyukur akan nikmat yang Allah berikan tidak menambah ataupun berdampak pada Allah, melainkan segala kebaikan akan kembali kepada hamba-Nya kembali Ayat-ayat yang memiliki pembahasan sama tentang dampak seseorang bersyukur atau kufur ada di beberapa surah, yaitu surah al-Nisā' [4]: 147 dan surah Lukmān [31]: 12.

\section{PENUTUP}

Berdasarkan data yang diperoleh sebagaimana yang telah dipaparkan, maka menghasilkan kesimpulan yaitu persamaan dan perbedaan penafsiran atas kata al-hamd dan al-syukr. Persamaan yang dapat ditemukan adalah baik al-Ṭabarī, al-Qurțubī, maupun ibn Kathīr sepakat bahwa al-hamd lebih umum dari al-syukr karena terjadi pada sifat yang berkenaan dengan diri sendiri dan pihak lain. Namun ibn Kathīr menambahkan bahwa al-syukr juga bisa disebut lebih umum karena diungkapkan melalui ucapan, perbuatan, dan niat. Perbedaannya adalah al-Ṭabarī menyebutkan bahwa al-hamd dan al-syukr sama, namun al-Qurțubī dan ibn Kathīr tidak menyetujui pendapat tersebut. Perbedaan ini terjadi karena al-Ṭabarī mengatakan al-ḥamd adalah sanjungan yang Allah tujukan kepada Zat-Nya, sekaligus perintah kepada hamba-Nya untuk memujiNya. al-Tabarī menyebutkan kedua kata tersebut sama berpatokan pada kebiasaan orang Arab mengucapkan al-hamd lillāh syukran dan saling mengganti penggunaannya. Sedangkan al-Qurțubī berargumen bahwa al-hamd merupakan sanjungan kepada yang dipuji karena sifatnya tanpa diiringi kebaikan dahulu, dan al-syukr adalah sanjungan kepada yang disyukuri disebabkan kebaikannya. Begitu juga dengan ibn Kathīr yang berpendapat bahwa kedua kata tersebut tidak bisa dikatakan sama, karena setiap katanya memiliki makna umum dan khusus sendiri.

\footnotetext{
${ }^{77}$ al-Ṭabarī, Tafsìr Jāmi' al-Bayān, J. 19, h. 460-469.

${ }^{78}$ Abū al-Fidā' Ismā'îl, Tafsīr Al-Qur'ān al- 'Ażìm, J. 6, h. 192-193.
} 
Makna Al-Hamd dan Al-Syukr dalam Tafsir

(Studi Analisis Metode Tafsir Muqarran)

\section{DAFTAR PUSTAKA}

A.G, Haryanto, dkk. Metode Penulisan dan Penyajian Karya Ilmiah. Jakarta: Kedokteran EGC, 2000.

Amrullah, Abdul Malik Karim. Tafsir al-Azhar. Jakarta: Pustaka Panjimas, 1986.

Anwar, Rasihan. Melacak Unsur-unsur Israilliyat dalam Tafsīr al-Tabarī dan Ibn Kathir. Bandung: Pustaka Setia, 1949.

AS, Abdullah. “Kajian KitabTafsir al-Jāmi' li aḥkām Al-Qur’ān Karya al-Qurțubī.” Jurnal al-I'jaz: Kewahyuan Islam PPS UIN SU (Januari-Desember 2018).

al-Ashfahān̄i, Rāghib. Mu’jam Mufradāt al-Fāz Al-Qur 'ān. Beirut: Dār al-Kitab al'Ilmiah, t.t.

Asriaty. "Menyoal Pemikiran Islam Syahrur." Istinbat Jurnal Hukum Islam. Vol. 13, No. 2 (Desember 2014).

al-Baghawī, Abū Muḥammad al-Husain bin Mas'ūd. Ma 'ālim al-Tanzīl, J. 1, Cet. IV. Mekah: Dār Ṭayyibah, 1997.

Baidan, Nashruddin. Metodologi Penafsiran Al-Qur'an. Yogyakarta: Pustaka Pelajar, 1998.

Baihaki, Egi Sukma. "Syukur dan Pujian Menurut Muhammad Shaleh Darat al-Samarani: Kajian atas (QS. al-Fātiḥah [1]: 2) Tafsīr Faị̣ al-Raḥmān.” Jurnal Tanzil Sekolah Tinggi Filsafat Islam Jakarta. Vol.1, No.2 (April 2016).

Bakir, Moh. "Konsep Maqāsid al-Qur’ān Perspektif Badī al-Zamān Sa‘īd Nursī (Upaya Memahami Makna Al-Qur’an Sesuai dengan Tujuannya).” Jurnal Elfurqonia AlMujtama'Pamekasan. (Agustus 2015).

al-Bakri, Ahmad Abdurrazaq. dkk. Taḥqiq Tafsīr al-Ṭabarī, terj. Ahsan Askan. Jakarta: Pustaka Azzam, 2007.

al-Baq̄ī, Muhammad Fuad 'Abd. Mu'jam al-Mufaḥras lì al-Faz Al-Qur 'ān al-Karìm. Kairo: Dār al-Hadīth, 2007.

“Biografi al-Ṭabarī dan al-Māturīdī serta Karyanya." Diakses, 31 Desember 2019, http:// studentsrepo.um.edu.my/5951/2/BAB 1 mac 2015.pdf.

al-Bukhārī, Muḥammad bin Ismā'īl Abū 'Abdillāh. Șaḥịh al-Bukhārī, tahqiq. Muḥammad Zahīr bin Nāṣir, J. 5, Cet. I. Mekakh: Dār Ṭauq al-Najah, 1442.

Chonyta, Didin. “Jāmi' al-Bayān fì Tafsīr Al-Qur’ān Karya Ibn Jarīr al-Ṭabarī.” Diakses, 31 Desember 2019, https://www.academia.edu/12630711/JAMI_AL-BAYAN FI_TAFSIR_AL-QUR_AN_KARYA IBN_JARIR AT-THABARI.

Djalal, Abdul. Ulumul Qur'an. Surabaya: Dunia Ilmu, 2000.

al-Farmawi, Abdul Hayyi. Metode Maudhu'̄ dan Cara Penghimpunannya, terj. Abdul Jaliel. Bandung: Pustaka Setia, 2002.

Fatmawati, Mila. dkk. "Analisis Semantik Kata Syukur dalam Al-Qur’an.” Jurnal alBayan UIN Sunan Gunung Djati Bandung. Vol.3, No.2 (2018).

al-Ghazālī, Muhammad. Tafsīr al-Ghazālì: Tafsir Tematik Al-Qur 'an 30 Juz (Surat 1-26), terj. Safir al-Azhar. Yogyakarta: Islamika, 2004.

al-Ghazālī, Abū Hāmid. Ihyā' Ulūm al-Dīn, Beirut: Dār al-Fikr, t.t. 
Hakim, A. Husnul. Ensiklopesi Kitab-kitab Tafsir (Kumpulan Kitab Tafsir dari Masa Klasik sampai Masa Kontemporer). Depok: eLSiQ, 2013.

al-Ḥamawī, Yāqūt. Mu’jam al-Udabā'. Beirūt: Mu'assasah al-Ma’ārif, 1999.

bin Hamzah, Azhari. “Analisis Gaya Bahasa Pujian dan Celaan dalam Al-Qur’an.” Disertasi Universitas Malaya Kuala Lumpur, 2010.

Hanafi, Muchlis M. Berguru kepada Sang Mahaguru. Tangerang: Lentera Hati, 2014.

Hasiah. "Syukur dalam Al-Qur'an." Jurnal Hikmah Pascasarjana IAIN Imam Bonjol Padang. Vol.6, No.2 (2012).

Hidayatullah, Tim Penulis IAIN Syarif. Ensiklopedi Islam Indonesia, Cet. II. Jakarta: Pustaka, Edisi Revisi, 2002.

al-Husain bin Muhammad, Abī al-Qāsim. Mu'jam Mufradāt al-Fāz Al-Qur 'ān. Beirūt: Dār al-Kitab al-'Ilmiyah.

Ichwan, Mohammad Nor. Studi Ilmu-ilmu Al-Qur 'an. Semarang: Rasail Media Group, 2008.

Islam, Dewan Redaksi Ensiklopedi. Ensiklopedi Islam, Cet. IV. Jakarta: PT Ichtiar Baru Van Hoev, 2001.

Isma'il, Muhammad Bakar. Ibnu Jarīr al-Ṭabarī wa Manhajuhu fì Tafsīr. Kairo: Dār alManar, 1991.

Ismail, Nurjannah. Perempuan dalam Pasungan (Bias Laki-laki dalam Penafsiran). Yogyakarta: LKiS Yogyakarta, 2003.

Istijano. Aplikasi Praktis Riset Pemasaran (Cara Praktis Meneliti Konsumen dan Pesaing). Jakarta: PT. Gramedia Pustaka Utama.

ibn Kathīr, Al-Imam Abū Fidā' Ismā'̄̄l ibn Umar. al-Bidayah wa al-Nihayah, J. 14. Beirut: Dār al-Fikr, 1990.

. Tafsìr Al-Qur 'ān al- 'Aż̄im. Beirut: Dār Țayyibah, 1420 H. . Tafsīr ibn Kathīr, Bandung: Sinar Baru Algensindo, 2000.

Khaeruman, Badri. Sejarah Tafsir Al-Qur 'an. Bandung: CV Pustaka Setia, 2004.

Madaniy, A. Malik. Menambah Nikmat Dengan Bersyukur. Jakarta Timur: Lajnah Pentashihan Mushaf Al-Qur'an, 2015.

. "Syukur dalam Perspektif Al-Qur`an.” Jurnal al-Zarqa Universitas Islam Negeri Sunan Kalijaga Yogyakarta. Vol.7, No.1 (2015).

Mahfud, Choirul. "The Power of Syukur: Tafsir Kontekstual Konsep Syukur dalam A1Qur’an.” Jurnal Lembaga Kajian Agama dan Sosial (LKAS) Surabaya. Vol.9, No.2 (2014).

Ibn Manẓūr. Lisān al- 'Arab, J. 9. Beirut: Dār Șādir.

Masduha. al-Alfaazh: Buku Pintar Memahami Kata-kata dalam Al-Qur 'an. Cet. I. Jakarta: Pustaka Kautsar, 2017.

al-Māward̄̄, Abū al-Ḥasan Alī bin Muḥammad. al-Nukat wa al-Uyūn. J. 4. Muwaqi’ alTafāsīr.

Mazwan, Nur Faizan. Kajian Deskriptif Tafsīr ibn Kathīr. Yogyakarta: Menara Kudus, 2002.

Mestika. Metode Penelitian Kepustakaan. Jakarta: Yayasan Obor Indonesia, 2004. 
Muḥammad, Al-Imām al-Ḥākim Abū 'Abdillāh. al-Mustadrak 'alā al-Ṣahihainain, ta'līq. Al-Imām al-Ẓahabī Syams al-Dīn Abū 'Abdillāh Muḥammad. J. 3. t.t.

al-Muṣalli, Ahmad bin Ibrahim bin Kholid. Tafsīr ibn Abī Hātim. t.t.

Namedia, "Metodologi Penafsiran Dr. Aisyah Abdurrahman (Bintu Syathi)." Diakses, 11 Oktober 2019, https://milahidayah.wordpress.com/2014/10/01/metodologipenafsiran-dr-aisyah-abdurrahman-bintu-syathi/.

Nasution, Abd Haris. Mansur, Muhammad. "Studi Kitab Tafsīr Al-Qur'ān al-'Az̄īm Karya Ibn Kathīr." Jurnal Ushuluddin Adab dan Dakwah IAI al-Mawaddah Warrahmah Kolaka, Vol. 1, No. 1 (2018).

Nurdin. "Analisis Penerapan Metode bi al-Ma'thūr dalam Tafsīr ibn Kathīr Terhadap Penafsiran Ayat-ayat Hukum.”,Jurnal Asy-Syir'ah Ilmu Syari'an dan Hukum, Vol. 47, No. 1 (2013).

Nurhaedi, Dadi. Studi Kitab Tafsir. Yogyakarta: Teras, 2004.

Pengembangan Bahasa, Penyusunun Kamus Pusat Pembinaan dan. Kamus Besar Bahasa Indonesia. Cet. IV. Jakarta: Balai Pustaka, 1990.

al-Qațān, Mannā Khalīl. Mabāḥith fì Ulūm Al-Qur 'àn, terj. Mudzakir, Studi Ilmu-ilmu al-Qur'an. Bogor: Pustaka Lintera Antar Nusa, 2009.

al-Qurțubī, Abū 'Abdillāh. al-Jāmi' li Ahkēmm Al-Qur 'an, taḥqiq. 'Abdullāh bin Ibran alMuhsin al-Turkī, J. 1. Beirut: Muassasah al-Risālah, 2006.

al-Qurțubī, Abū 'Abdillāh. al-Jāmi' li Ahkām Al-Qur 'an, taḥiq. Aḥmad al-Bardūnī dan Ibrāhīm Aṭ̂īsiy, J. 1, Cet. II. al-Qāhirah: Dār al-Kutub al-Misriyah, 1964. . al-Jāmi 'li Ahkām al-Qur 'an, terj. Fathurrahman, dkk. Jakarta: Pustaka Azzam, 2010.

al-Rāzī, Ibn Abī Ḥatim. Tafsīr ibn Ab̄̄ Hātim. J. 2. t,t.

Ridā, Muhammad Rasȳ̄d. Tafsìr Al-Qur 'ān al-Hakìm (al-manār). Beirūt: Dār al-Kutub al-'Ilmiyah, 1999.

Ridha, Ali Hasan. Sejarah dan Metodologi Tafsir, Terj. Ahmad Akrom. Jakarta: Rajawali Press, 1994.

RI, Kementerian Agama. Al-Qur'ān Kemenag in Microsoft Word. Jakarta: Lajnah Pentashihan Mushaf Al-Qur'an.

al-Ṣābūn̄̄, Muhammad 'Ālī. Rawāi ' al-Bayān Tafsīr Ayat al-Ahkām min Al-Qur’an. Damaskus: Maktabah al-Gazālī, 1977.

Sahabuddin. Ensiklopedia Al-Qur 'an: Kajian Kosakata. Jakarta: Lentera Hati, 2007.

Sa'id, 'Abd al-Satar Fathullah. Madkhul ilā Tafsīr al-Maudhu'̄̄, J. 2. al-Qāhirah: Dār alTauzi' wa al-Nasyr al-Islāmiyah, 1991.

Șālih, Abdul Qadir Muhammad. al-Tafsīr wa al-Mufasirūn fì al-Athar al-Hadith. Beirut: Dār al-Ma'rifah, 2003.

al-Ṣāliḥ, Șubḥi. Mabahīth fì Ulūm Al-Qur 'ān, Cet. III. Beirut: Dār al-'Ilm li al Malayin, 1972.

Saltut, Mahmud. Tafsir al-Qur `ān al-Karim. Bandung: Sinar Baru Algensindo, 2000.

al-Șan'ān̄̄, Abū Bakr 'Abd al-Razzāq ibn Hamām. Muṣannaf 'Abd al-Razzāq, tahqiq. Habīb al-Rahman al-A’ẓamī, J. 10, Cet. II. Beirut: al-Maktab al-Islāmī, 1403. 
al-Shiddieqy, Teungku Muhammad Hasbi. Ilmu-ilmu Al-Qur 'an, Cet. II. Semarang: Pustaka Rizki Putra, 2009.

Shihab, M. Quraish. "Ibn Jarīr al-Ṭabarī: Guru Besar para Ahli Tafsir.” Jurnal Ulumil Qur`an. Vol. 1, No. 1 (1989).

. Tafsīr al-Mishbāh: Pesan, Kesan, dan Keseriasan Al-Qur'an. J. 1, Cet. 5. Jakarta: Lentera Hati, 2002, 32.

. Kaidah Tafsir. Tangerang: Lentera Hati, 2015.

Mukjizat Al-Qur`an. Bandung: Anggota Ikapi, 2007.

Wawasan Al-Qur 'an: Tafsir Maudhu'i atas Pelbagai Persoalan Umat. Bandung: Mizan, 1996.

Solahudin. "Neraka dalam Al-Qur'an dan dalam Pandangan Sarjana Muslim.” Tesis SPS UIN Syarif Hidayatullah Jakarta, 2017

Srifariyati. "Manhaj Tafsir Jami’ al-Bayan Karya Ibnu Jarīr al-Ṭabarī.” Jurnal Madaniyah STIT Pemalang. Vol. 7, No. 2 (Agustus 2017).

Sugiyono, Sugeng. Lisan dan Kalam Kajian Semantik Al-Qur’an. Yogyakarta: Sunan Kalijaga Press, 2009.

Surakhmad, Winarno. Pengantar Penelitian Ilmiyah. Bandung: Tarsito, 1998.

Suwendra, Wayan. Metodologi Penelitian Kualitatif (dalam Ilmu Sosial, Pendidikan, Kebudayaan, dan Keagamaan). Bandung: NilaCakra Publishing House, 2018.

al-Suyuṭī, 'Abd al-Rahman bin Abī Bakar Jalāl al-Dīn. al-Dur al-Manthūr fì al-Ta'wìl bi al-Ma'thūr, J. 2. t,t. . Asbāb al-Nuzūl: Sebab Turunnya Ayat Al-Qur an, terj. Tim Abdul Hayyie, Cet. I. Jakarta: Gema Insani, 2008.

binti al-Syāti', 'Āisyah 'Abdurrahmān. al-I’jāz al-Bayānì li Al-Qur 'ān; Wa masāiluhu ibn al-Azraq. Mesir: Dār al-Ma'ārif, 1987.

Syibromalisi, Faizah Ali. dan Jauhar Azizy. Membahas Kitab Tafsir: Klasik-Modern. Tangerang Selatan: Lembaga Penelitian UIN Syarif Hidayatullah Jakarta, 2009.

al-Ṭabarī, Abū Ja'far Muhammad bin Jarīr. Tafsir Jāmi' al-Bayān fì Ta'wīl Al-Qur 'an, taḥqiq. Aḥmad Muḥammad Syākir, Cet. I. Beirut: Muassasah al-Risālah, 2000. . Tafsìr Jāmi'al-Bayān. Beirut: Dār al-Fikr, 1995.

. Tafsir Jāmi'al-Bayān, terj. Ahmad Abdurrazzaq al-Bakri, dkk. Jakarta: Pustaka Azzam, 2007.

al-Ṭabrānī, Abū al-Qāsim Sulaimān ibn Aḥmad. al-Mu'jam al-Ausaț, taḥqiq. Ṭāriq ibn 'Iwadhullāh, 'Abd al-Muhsin ibn Ibrāhīm, J. 2. al-Qāhirah: Dār al-Ḥaramain, 1415.

Taimiyyah, Ibnu. Muqaddimah fì Ushul al-Tafsīr. Kuwait, 1971.

Tangngareng, Tasmin. Menyelam ke Semesta Zikir: Menyikap Makna dan Pesannya dalam Hadis Nabi Saw, Cet. I. Makassar: Alauddin University Press, 2013.

Trigiyatno, Ali. "Pandangan Ibnu Jarir al-Ṭabarī tentang Kedudukan Wanita sebagai Hakim dan Imam Shalat." Jurnal Muwazah IAIN Pekalongan. Vol. 6, No. 2 (2012).

Ulama'i, A. Hasan Asy'ari. Membedah Kitab Tafsir Hadis, Cet. I. Semarang: Walisongo 
Makna Al-Hamd dan Al-Syukr dalam Tafsir

(Studi Analisis Metode Tafsir Muqarran)

Press, 2008.

Ushama, Thameem. Metodologi Tafsir Al-Qur'an; Kajian Kritis, Objektif dan Komprehensif, terj. Hasan Basri dan Amroeni. Jakarta: Riora Cipta, 2000.

Wekke, Ismail Suwardi. “Analisis Gaya Pujian dalam Al-Qur’an.” Jurnal Sekolah Tinggi Agama Islam Negeri Sorong (2018).

Yusuf, Mundzirin. "Peradaban Dinasti Mamluk di Mesir.”,Jurnal Thaqafiyat, Vol. 16, No. 2 (Desember 2015).

Al-Zahabī, Muhammad Husein. al-Tafsīr Wa al-Mufasirin. Mesir: Dār Al-Kutub AlHadithah, 1961.

al-Ẓahab̄i, Syams al-Dīn Muhammad bin Aḥmad 'Uthman. Siyār A'lām al-Nubalā', Cet. I. Beirūt: Mu'assasah al-Risālah.

Zahwa, Abu. Tafsir Surah al-Fātiḩah Menurut 10 Ulama Besar Dunia. Jakarta: Pustaka Azzam, 2010.

ibn Zakariya, Ahmad Ibn Faris. Mu'jam Maqayis al-Lughah, J. 3. Beirut: Dār al-Fikr.

Zulharman, Syaikh Abdurrahman bin Nashir al-Sa'di. Taisir al-Karìm al-Rahman fì Tafsìr Kalīm al-Mannān. KSA: Dār Ibn al-Jauzi, 1426.

al-Zamakhsyarī, Abū al-Qāsim Maḥmūd bin 'Umar. al-Kasyāf 'an Haqāiq al-Tanzīl wa 'Uyūn al-Aqāwīl fì Wujūh al-Ta'wūl, J. 1, Cet, I. Beirut: Dār al-Fikr, 1977. 